\title{
Programming of Cell Resistance to Genotoxic and Oxidative Stress
}

\author{
Ilya O. Velegzhaninov ${ }^{1,2, *}$ (D), Vitaly A. Ievlev ${ }^{3}$, Yana I. Pylina ${ }^{1}$, Dmitry M. Shadrin ${ }^{1}$ and \\ Olesya M. Vakhrusheva ${ }^{2}$ \\ 1 Institute of Biology of Komi Science Centre of Ural Branch of RAS, Syktyvkar 167982, Russia; \\ yanapylina@yandex.ru (Y.I.P.); shdimas@yandex.ru (D.M.S.) \\ 2 Polytechnical Institute of Vyatka State University, Kirov 610000, Russia; nimf04ka@mail.ru \\ 3 Biology department of St. Olaf College, Northfield, MN 55057, USA; ievlev1@stolaf.edu \\ * Correspondence: vellio@yandex.ru; Tel.: +7-909-121-9693
}

Received: 29 October 2017; Accepted: 31 December 2017; Published: 2 January 2018

\begin{abstract}
Different organisms, cell types, and even similar cell lines can dramatically differ in resistance to genotoxic stress. This testifies to the wide opportunities for genetic and epigenetic regulation of stress resistance. These opportunities could be used to increase the effectiveness of cancer therapy, develop new varieties of plants and animals, and search for new pharmacological targets to enhance human radioresistance, which can be used for manned deep space expeditions. Based on the comparison of transcriptomic studies in cancer cells, in this review, we propose that there is a high diversity of genetic mechanisms of development of genotoxic stress resistance. This review focused on possibilities and limitations of the regulation of the resistance of normal cells and whole organisms to genotoxic and oxidative stress by the overexpressing of stress-response genes. Moreover, the existing experimental data on the effect of such overexpression on the resistance of cells and organisms to various genotoxic agents has been analyzed and systematized. We suggest that the recent advances in the development of multiplex and highly customizable gene overexpression technology that utilizes the mutant Cas9 protein and the abundance of available data on gene functions and their signal networks open new opportunities for research in this field.
\end{abstract}

Keywords: cell programming; stress resistance; gene overexpression; radiation; oxidative stress; chemical genotoxins; malignant transformation; diversity of mechanisms

\section{Introduction}

Genotoxic stress, including oxidative stress, causes DNA damage. The evolutionary conservative cellular mechanisms of DNA-damage prevention and response (DNA repair, defense against reactive oxygen species, cell cycle checkpoints, and apoptosis) protect cells from mutations and tissues from acquiring malignancy [1,2]. On the one hand, genotoxic stress can induce carcinogenesis, on the other hand, it is used to treat cancer. The advancement of knowledge on regulation of stress-resistance in cells and organisms is extremely important for increasing the effectiveness of cancer treatment. In particular, the creation of new in vitro models of upregulated cell resistance to genotoxic and oxidative stresses allows for expanding the spectrum of in vivo models for studies of genetic regulation of carcinogenesis. In addition, it was suggested multiple times that gene therapy of normal tissues surrounding tumor can be used for increasing their resistance to genotoxins. This can help to minimize the negative side effects of cancer treatment by chemotherapy and radiation therapy [3-5]. This technology can also be used for gene therapy and gene prophylaxis of diseases that are associated with increased sensitivity to DNA-damaging agents [6]. Understanding the mechanisms of cellular stress resistance, and especially resistance to oxidative stress, is one of the most important tasks in studies of lifespan extension $[7,8]$. Knowledge of stress-resistance is also important when creating new genetically modified varieties of 
plants and breeds of animals [9]. Additionally, the problem of prolonged exposure of astronauts to cosmic ionizing radiation is a great challenge that needs to be addressed in order to make deep space expeditions possible $[10,11]$. One of the possible solutions is a pharmacological or genotherapeutic enhancement of human radioresistance. Lastly, cell cultures with multiple enhanced stress resistance can find application in recombinant therapeutic protein production [12]. To achieve all of the objectives listed, except for the last one, it is necessary to ensure that tissue function and cells' ability to elicit apoptotic and cell cycle responses are both not affected as a result of genetic engineering interventions. Ideally, an increase in resistance to genotoxic stress should lead to a decrease in the frequency of somatic mutations and neotransformations at the organismal level.

The functions of many stress-response genes have been well studied. Signal-cascade networks of gene activation in response to various damaging agents have also been elucidated. Such knowledge can help in identifying potential gene targets and their combinations for transcriptional activation increasing resistance to genotoxic and oxidative stress. However, without an array of experimental data, it is not possible to accurately predict the results of such activations. Moreover, it is difficult to prognosticate the biological consequences of varying degree overexpressions of one and the same gene. The discovery of the CRISPR/Cas adaptive immunity and the development of methods for its application for genome [13] and epigenome editing [14-18] significantly expands the possibilities for further studies of stress resistance programming. In particular, relatively simple and adjustable multiplex overexpression of genes by nuclease-null Cas9 (dCas9) can successfully activate multi-subunit molecular complexes or entire signal cascades. Moreover, this technology provides the activation of genes in endogenous context, covering splice variants [16]. These advantages distinguish it from the previously dominant gene overexpression technology, which relies on introduction of cDNA into the cell under a constantly active or inducible promoter. To date, there are very few works in the literature that used CRISP/dCas9 for gene overexpression. Most of the articles are devoted to the optimization of the technology and its application in various fields of biological science. However, this technology has already begun to prove its high potential. For example, it was shown the possibilities of reactivation of silenced tumor supressors in vitro [19] and the regulation of tumor phenotypes in vivo [20]. Thus, we expect a new round of research in the field of genetic and epigenetic regulation of resistance to genotoxic stress. In this regard, the review discusses the current state of knowledge about modulation of resistance to genotoxic and oxidative stress by genes overexpression in case of normal and cancer cells, as well as whole organisms. To assess the potential of genetic regulation of stress-resistance the review also discusses transcriptomic studies in cancer cells with different levels of radioresistance.

\section{The Diversity of Mechanisms of Stress Resistance in Cancer Cells}

Mechanisms for development of genotoxic and oxidative stress resistance in tumor cells are well described in a number of reviews [21-24]. Clearly, cells lacking the capacity for apoptosis or irreversible cell cycle arrest will exhibit a resistant phenotype due to their continued ability to proliferate even under severe genotoxic stress conditions. Continued exposure to genotoxins in a combination with abnormal response to DNA damage can lead to a further loss of control mechanisms and can increase resistance to stress in tumor cells. For example, this can happen through the missense mutations in tumor suppressors. It can also be induced by a shift in a balance between homologous (HR) and non-homologous end-joining (NHEJ) in double strand break DNA repair [22]. In addition, resistance to genotoxic stress is associated with the activation of oncogenes $\mathrm{N}$-ras, $\mathrm{K}$-ras [25,26], MET [27], and YAP [28]. Radioresistance is also associated with the activity of the Sox2 and Oct3/4 genes that induce pluripotency and stem cell-like properties in cancer cells [29]. 
Due to the risk of carcinogenesis, the mechanisms described above cannot be used as practical targets for induction of cellular stress-resistance. However, stress resistance of tumor cells is often formed by the mechanisms that are not associated with initiation of malignant transformation. As mentioned above, alteration in components of genome stability machinery could lead to an increase in mutation rate in tumors, and result in an increased genetic heterogeneity of cells. This heterogeneity facilitates the rapid selection of cells subpopulations that are resistant to stress [23]. The possibility of this selection-based mechanism of resistance has been repeatedly confirmed in direct selection experiments [30-32]. However, there is also evidence that stress-resistance can be induced at the epigenetic level, independently from the selection process [33]. The resistance that is developed by selection or independently of it often results from the overexpression of the genes encoding transporter proteins, which support enhanced drug efflux [24]. In many cases, overactivation of DNA damage recognition and repair as well as detoxification of free radicals are also observed. For example, Rad51 gene, which is involved in homologous recombination is overexpressed in a variety of human cancer types. This often leads to chemo-resistance of these tumors [34]. An inverse correlation was observed between the expression of the excision repair gene ERCC1 and the sensitivity to platinum treatment of various types of tumors [35]. An enhancement of excision repair activity in lung cancer cells can also be associated with a SIRT1 dependent increase in XPA sensitivity to DNA damage [36]. Expression of the antioxidant defense gene-MnSOD—correlates with resistance to doxorubicin and mitomycin $\mathrm{C}$ in gastric carcinoma cells [37]. RPA1 gene, which is involved in DNA replication and repair is overexpressed as a result of selection of a radioresistant clone in esophageal carcinoma cell line TE- 1 . Inhibition of RPA1 in that radioresistant clone restored the normal sensitivity to ionizing radiation [38].

There are many other examples of an established link between genotoxic stress resistance and overexpression of genes involved in DNA repair, xenobiotic detoxification, or efflux. However, the diversity of possible mechanisms of resistance seems to be even larger. This is supported by the studies comparing transcriptomes of similar cell lines that differ in sensitivity to genotoxic agents. For example, a comparison of ten microarray studies performed on cancer cells with different degrees of resistance to ionizing radiation did not identify any commonly overexpressed genes [39-48]. We could not find a gene that would be significantly overexpressed in three or more comparison pairs. Approximately $95 \%$ of the total number of overexpressed genes were observed in only one study and were absent in others (Figure 1). Interesting, that among the genes overexpressed in two different studies most are interferone induced genes, which involved in response to virus infection [49]. This fact shows once again that different systems can be involved in the regulation of resistance to genotoxic stress.

Thus, the diversity of pathways leading to resistance in cancer cells, allows for us to suggest a wide range of possibilities for increasing resistance of normal cells to genotoxic and oxidizing agents. We suppose, that if we exclude all of the targets that affect cell cycle control, apoptosis, proliferation, and differentiation, we can enhance stress-resistance without the risk of increasing malignancy. Moreover, the increased efficiency of cellular defense systems should in theory lead to a decrease in carcinogenesis. This assumption is supported by the fact that the activity of DNA repair systems inversely correlates with the risk of neotransformation [50]. In addition, a decrease in alkylating agent-induced carcinogenesis has been repeatedly demonstrated upon overexpression of the gene $O^{6}$-methylguanine-DNA methyltransferase (MGMT), which is responsible for DNA damage recognition and repair [51-56]. 


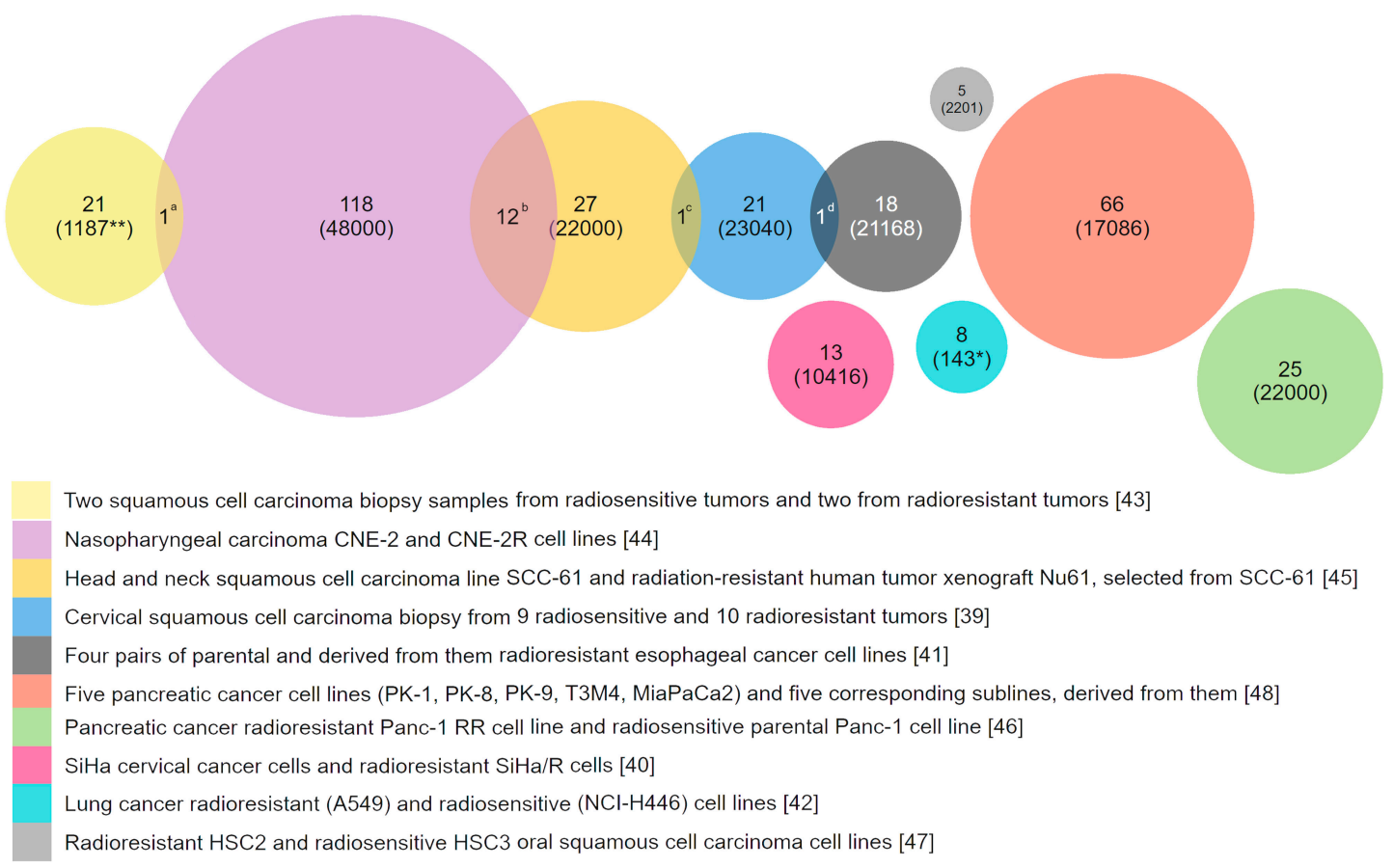

Figure 1. Genes that are overexpressed in radioresistant cancer cells in comparison with parental or similar but radiosensitive cells. The results of ten studies performed with microarrays were used. Only 15 of the 337 overexpressed genes are repeated twice in different studies: ${ }^{a}$-C-JUN; ${ }^{b}-C X C L 10$, IFI44, IFIH1, IFITM1, STAT1, DDX60, HERC6, IFI27, PLSCR1, IFIT1, IFI35, IFIT3; c_ISG15; d _ERP70. Numbers in parenthesis is the quantity of transcripts analyzed. *-Genes that are involved in apoptosis, DNA repair, cell cycle control, cell proliferation and other mechanisms of stress response. ** —only tumor-related genes.

\section{Genotoxic Stress Resistance in Experimental Models with Gene Overexpression}

Change in gene transcription is only one of the existing ways of readjusting the mechanisms of stress resistance. Another way of establishing stress resistance is a pharmacological targeting of proteins and signaling cascades, which seem more acceptable for clinical applications. However, accumulation of experimental data on the effects of overexpression of individual genes and their combinations is required to develop pathways of stress-resistance regulation that might help finding new pharmacological targets. The literature on the effects of overexpression of stress-responsive genes on the resistance of cells and organisms to genotoxins is overwhelmingly broad. However, we attempted to systematize such published experimental data based on overexpressed genes, on the effect on stress resistance and on genotoxicants. Being mindful of the scale and the variety of the published studies, in our analysis we chose a simple algorithm of grouping the target genes by their function. The resulting lists of reviewed published reports are presented in Tables 1 and 2 for in vitro and in vivo studies, respectively. One interesting, but not totally surprising, finding of our analysis was that most studies driven by a targeted hypothesis (about involvement of a particular gene in stress resistance based on previous experimental evidence) found that overexpression of the gene did increase stress resistance. On the other hand, it seems that in case of randomly selected targets, the predominant outcome would be sensitization to stress, likely due to a disruption of normal gene activity regulation. 
As suggested above, the two most promising gene categories to enhancing resistance by overexpression are the genes involved in DNA damage recognition and repair, as well as the genes that are responsible for efflux and detoxification of xenobiotics. Overexpression of these genes tends to be the most successful strategy of enhancing resistance to genotoxic stresses without the risk of increasing the frequency of neoplastic transformations. However, overexpression of these targets does not always lead to an expected/desired outcome. Firstly, an increase in survival can mask the decrease in DNA repair quality. For example, overexpression of the gene encoding DNA polymerase $\beta$ in CHO cells lead to an increase in survival after treatment with cisplatin, melphalan, or mechlorethamine. However, it also dramatically increased the frequency of mutations in surviving cells. DNA polymerase $\beta$, the most error prone eukaryotic DNA polymerase [57-60] has been repeatedly shown to be the cause of the phenomenon mentioned Therefore, the required outcome and endpoints used should be selected carefully. Secondly, the effect of overexpression of various single elements of a repair or detoxification system/pathway can sometimes produce an effect that is opposite of the expected one. At the cellular level, the two main groups of reasons for this are (a) the imbalance between the elements of the protective systems; and, (b) the absence of the expected relationship between the level of gene transcription and the activity of the gene product. The latter primarily applies to all of the proteins whose activity depends on post-translational modifications. The mismatch between the mRNA levels and the protein function may also arise when a gene encodes only one subunit of multisubunit protein complexes. For example, stability of the DNA repair protein XPC depends on the levels of HR23A and HR23B proteins [61], therefore the overexpression of XPC gene may not be sufficient to enhance nucleotide excision repair. As consistent with this, an averaged quantitative relationship between the levels of mRNA and corresponding protein tends to be weak [62]. However, estimations of this correlation are still the subject of discussion and differ widely in the range from 0.21 to 0.9 [63]. In exceptional cases, for example, in the case of ribosomal proteins, mRNA can be a repressor of translation of its own product. This phenomenon is known to occur for the RpS3 protein that is involved in stress responses [64].

The imbalance of protective systems resulting from overexpression of individual genes may be caused by several different mechanisms. First, it can be driven by the imbalance in productivity of successive stages of a single cascade. For example, a wide range of modified bases in S. cerevisiae is excised using MAG1 (3-methyladenine DNA glycosylase). The abasic sites that are generated by MAG1 are processed normally by the major yeast APN1-encoded AP endonuclease. Disproportionately high expression of MAG1 when compared to the AP endonuclease increases spontaneous mutation by up to 600-fold in S. cerevisiae and by 200-fold in E. coli [65]. CHO cells with overexpressed MPG gene are more sensitive to alkylating agent $N$-methyl- $N^{\prime}$-nitro- $N$-nitroso-guanidine (MNNG) that is also associated with excessive accumulation of abasic sites [66].

Secondly, there are situations when an increase in resistance to one agent is accompanied by sensitization to others. For example, overexpression of APE1 increases the resistance of $\mathrm{CHO}$ cells to dioxolane cytidine [67], but it sensitizes cells to agents, which are activated by reduction reactions. This happens because the product of APE1 gene has a RedOx function in addition to AP endonuclease activity [68]. Another mechanism is a shift in balance between the two competing processes. For example, the overexpression of XRCC1 required for base excision repair (BER) slows gap-filling, because of the competition of BER with nucleotide excision repair for the PCNA protein [69].

The listed nuances of regulation of resistance to genotoxic stress explain the opposite outcomes observed during the overexpression of the same genes in different experiments (Tables 1 and 2). The same opposite outcomes are observed on the level of functional groups of gene, as obtained using PANTHER classification system [70,71]. The classification shows that researchers mainly chose the genes encoding nucleic acid binding proteins and proteins that catalyze redox reactions. This is expected, since the many proteins of these groups are involved in DNA repair and oxidative stress defence, respectively. At the same time, if we divide the experiments that are based on the direction of the effect on stress-resistance, the ratio of the functional groups does not change significantly (Figure 2). 
This means that we cannot say that in fact overexpression of the genes of one of these functional groups increases the stress resistance more effectively than the overexpression of the genes of the other group. At the level of the whole organism, potential disruptions of functional interactions between cells, tissues, organs, and organ systems are added to the intra-cellular mechanisms of imbalance listed above. But improvements in survival, decrease in frequency of mutations, fewer incidence of cancer, and some others desirable outcomes are still observed as a result of overexpression of stress-responsive genes in a number of studies, which holds promise (Table 2).

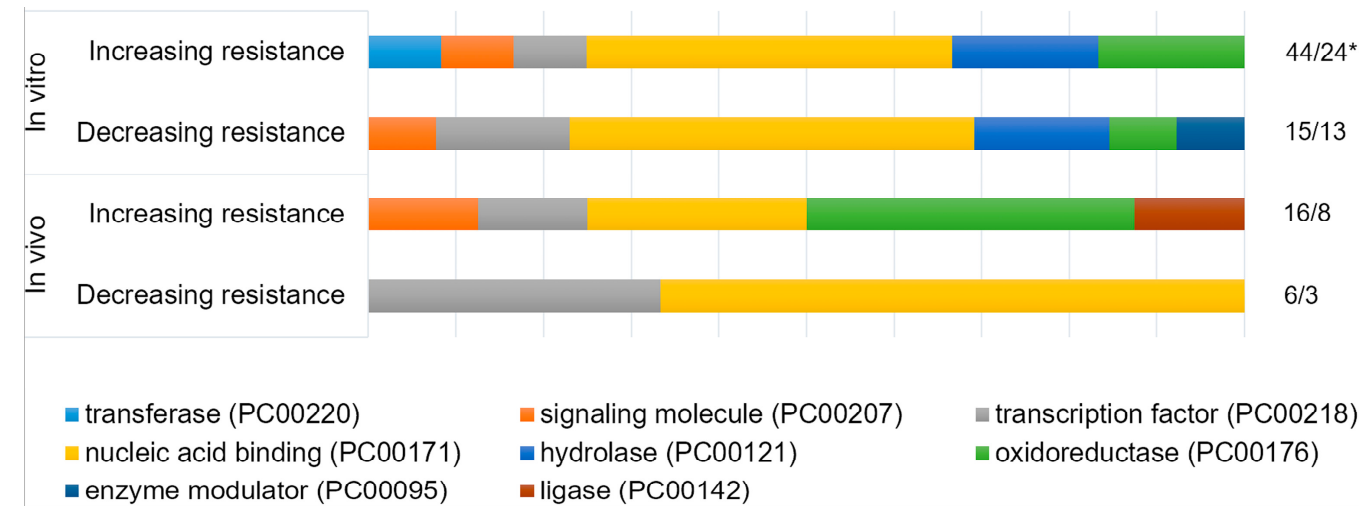

Figure 2. The functional classification of overexpressed genes using PANTHER classification system. Human orthologues of genes listed in Table 1 were divided into two groups, depending on the effect of their overexpression on the resistance of cells ("In vitro"). The same division was performed for orthologues of genes listed in Table 2 ("In vivo"). Each groups was classified using PANTHER Protein class ontology [70,71]. *-number of analyzed genes/total number of hits to "PANTHER protein class" classification.

In addition to the above, there are, apparently, many other factors that can radically change the influence of overexpression of certain genes on cellular stress-resistance. This is supported by the cell line specific effect of overexpression of the proto-oncogene HER2/neu in human breast and ovarian cancer cells. In six different cell lines, overexpression led to either a decrease, or an increase in sensitivity to chemotherapeutic agents of different classes [72]. These experimental data provide additional evidence in favor of the need for further studies of genetic regulation of stress resistance in normal and cancerous cells, as well as the stress-resistance of an organism as a whole.

\section{Prospects}

The decrease in stress-resistance of cells in the variety of experiments described above is largely caused with the multicomponent nature of stress response mechanisms that the studied genes participate in. Numerous experimental data that support the high efficiency of overexpression of the MGMT gene support confirm this assumption (Tables 1 and 2). Product of this gene solely performs recognition and repair of damaged DNA bases, in contrast to most other elements of cell protective systems that operate in cooperation with many other gene products [73]. When considering the accumulated detailed knowledge of such interactions, the development of multiplex gene activation systems with mutant RNA-guided Cas9 protein opens up the widest opportunities for studying the regulation of stress resistance. Multiplex activation using one large [74] or a number of small [16] plasmids, using activators with different degrees of efficiencies, allows for selecting the appropriate range of activation. To some extent, the level of overexpression of individual genes can be adjusted by selecting sgRNA for sequences that are located at different distances from the transcription start site. 
Table 1. Effect of overexpression of stress responsive genes on resistance to genotoxic agents in vitro.

\begin{tabular}{|c|c|c|c|c|}
\hline $\begin{array}{l}\text { Gene (Gene ID *; Origin } \\
\text { If Different) }\end{array}$ & Cells & Agents & $\mathbf{R} *$ & References \\
\hline \multicolumn{5}{|c|}{ Genes involved in DNA damage recognition and repair } \\
\hline RPA3 (6119) & $\begin{array}{l}\text { Human nasopharyngeal carcinoma } \\
\text { (CNE2, HK1) }\end{array}$ & X-ray & $\uparrow$ & [75] \\
\hline XPA (7507) & SV-40 transformed primary human cells & UV & $\uparrow$ & [76] \\
\hline $\begin{array}{l}\text { APN1 (853746; yeast) coding } \\
\text { homolog of mammalian APE1 }\end{array}$ & Chinese hamster (CHO-9) & $\begin{array}{l}\mathrm{MMS} \\
\mathrm{H}_{2} \mathrm{O}_{2}\end{array}$ & $\begin{array}{l}1 \uparrow \\
\uparrow \\
\end{array}$ & $\begin{array}{l}{[77]} \\
{[77]}\end{array}$ \\
\hline APE1 (328) & Chinese hamster $(\mathrm{CHO})$ & $\begin{array}{l}\text { dioxolane cytidine } \\
\gamma \text {-ray } \\
\text { alkylating agents } \\
\mathrm{H}_{2} \mathrm{O}_{2} \\
\text { mitomycin C, porfiromycin, } \\
\text { daunorubicin and aziridinyl } \\
\text { benzoquinone (drugs that are } \\
\text { activated by reduction) } \\
\text { alkylating agents }\end{array}$ & $\begin{array}{l}\uparrow \\
0 \\
0 \\
0\end{array}$ & $\begin{array}{l}{[67]} \\
{[67,78]} \\
{[67,68,78]} \\
{[67]}\end{array}$ \\
\hline $\begin{array}{l}\text { Chimeric MGMT (4255) + } \\
\text { APE1 (328) }\end{array}$ & Human cervix adenocarcinoma (HeLa) & alkylating agents & $\uparrow$ & [80] \\
\hline Ки70 (2547) & Human renal carcinoma $786-\mathrm{O}$ & $\gamma$-ray & $\uparrow$ & [81] \\
\hline $\begin{array}{l}\text { Ku70 (2547; human) + Ки80 } \\
\text { (34930; human) }\end{array}$ & Rat cell lines Rat-1 and R708 & X-ray & $\downarrow$ & [82] \\
\hline DNA-PK (5591) & Human promyelocytic leukemia HL60 & adriamycin & $\uparrow$ & [83] \\
\hline \multirow{3}{*}{ Rad51 (5888) } & Mammalian cells & \multirow{3}{*}{$\begin{array}{l}\gamma \text {-ray } \\
\text { etoposide, hydroxyurea, } \\
\text { thymidine } \\
\text { mitomycin C }\end{array}$} & $\uparrow$ & {$[84,85]$} \\
\hline & Chinese hamster (V79) & & $\uparrow$ & [86] \\
\hline & Mouse hybridoma cells & & $\uparrow$ & [85] \\
\hline Prpf19 (27339) & $\begin{array}{l}\text { Human umbilical vein/vascular } \\
\text { endothelium cells (HUVECs) }\end{array}$ & $\begin{array}{l}\text { bleomycin, } \\
\text { DL-buthionine-sulfoximine }\end{array}$ & $\uparrow$ & [11] \\
\hline ALC1 (9557) & Human osteosarcoma U2OS cells & phleomycin & $\downarrow$ & [87] \\
\hline Lig III (3980) & Human cervix adenocarcinoma (HeLa S3) & MNNG & $\uparrow$ & [88] \\
\hline \multirow[t]{2}{*}{ DNA pol $\beta$ (5423) } & Chinese hamster $(\mathrm{CHO})$ & $\begin{array}{l}\text { cisplatin, melphalan, } \\
\text { mechlorethamine }\end{array}$ & $\uparrow \downarrow$ & [57] \\
\hline & Mouse embryo fibroblast (MEF) & MMS & $\uparrow 0 \downarrow$ & [60] \\
\hline \multirow{2}{*}{$\begin{array}{l}\text { Tag (947137; E. coli) coding } \\
\text { methyladenine DNA } \\
\text { glycosylase I }\end{array}$} & Chinese hamster (V79) & $\begin{array}{l}\text { MMS, MNU, EMS } \\
\text { MNU, ENU }\end{array}$ & $\begin{array}{l}\uparrow \\
0\end{array}$ & $\begin{array}{l}{[89,90]} \\
{[90]}\end{array}$ \\
\hline & $\begin{array}{l}\text { Murine fibroblast (NIH3T3) and murine } \\
\text { H1 melanoma cells (B78) }\end{array}$ & $\begin{array}{l}\text { MNU, MNNG, DMS, } \\
\text { temozolomlde }\end{array}$ & 0 & {$[91]$} \\
\hline $\begin{array}{l}\text { AlkA (947371; E. coli) coding } \\
\text { methyladenine DNA } \\
\text { glycosylase II }\end{array}$ & Chinese hamster (V79 and Irs1) & DMS, EMS, MMS & $\uparrow$ & [92] \\
\hline \multirow{5}{*}{ MPG (4350) } & Chinese hamster (V79 and Irs1) & $\begin{array}{l}\text { DMS, EMS, MMS } \\
\text { MMS }\end{array}$ & $\begin{array}{l}\uparrow \\
\downarrow\end{array}$ & $\begin{array}{l}92] \\
{[93]}\end{array}$ \\
\hline & \multirow[t]{2}{*}{ Chinese hamster $(\mathrm{CHO})$} & $\begin{array}{l}\text { bis-chloroethylnitrosourea, } \\
\text { melphalan }\end{array}$ & 0 & [94] \\
\hline & & DMS, EMS, MMS & 0 & [95] \\
\hline & & MMS, MNNG & $\downarrow$ & {$[66]$} \\
\hline & Mouse embryo fibroblast (MEF) & temozolomide & $\downarrow$ & {$[96,97]$} \\
\hline $\begin{array}{l}\text { FPG }(946765 ; \text { E. coli) coding } \\
\text { homolog of mammalian OGG1 }\end{array}$ & $\begin{array}{l}\text { Chinese hamster (CHO and V79) } \\
\text { Chinese hamster (CHO) }\end{array}$ & $\begin{array}{l}\gamma \text {-ray } \\
\text { aziridine }\end{array}$ & $\uparrow$ & {$[98]$} \\
\hline dOGG1 (31806) & Drosophila S2 cells & $\begin{array}{l}\text { paraquat, } \mathrm{H}_{2} \mathrm{O}_{2} \\
S \text {-nitroso- } \mathrm{N} \text {-acetylpenicillamine }\end{array}$ & $\begin{array}{l}\downarrow \\
\uparrow\end{array}$ & $\begin{array}{l}{[100]} \\
{[100]}\end{array}$ \\
\hline OGG1 (4968; human) & Chinese hamster (AA8 and AS52) & $\begin{array}{l}\text { potassium bromate or } \\
\text { [R]-1-[(10-chloro-4-oxo- } \\
\text { 3-phenyl-4H-benzo[a] } \\
\text { quinolizine-1-yl)-carbonyl]- } \\
\text { 2-pyrrolidinemethanol plus light }\end{array}$ & $\uparrow$ & [101] \\
\hline ERCC1 (2067; human) & Chinese hamster (AA8) & $\begin{array}{l}\text { melphalan, cisplatin } \\
\text { UV }\end{array}$ & $\begin{array}{l}\downarrow \\
0 \\
\end{array}$ & $\begin{array}{l}{[102]} \\
{[102]}\end{array}$ \\
\hline NTH (947122; E.coli) & Chinese hamster (XRS7) & $\begin{array}{l}\gamma \text {-ray } \\
\mathrm{H}_{2} \mathrm{O}_{2} \\
\text { bleomycin }\end{array}$ & $\begin{array}{l}0 \\
\uparrow \\
\downarrow\end{array}$ & $\begin{array}{l}{[103]} \\
{[103]} \\
{[103]}\end{array}$ \\
\hline Ogt (945853; E. coli) & Mammalian cells & alkylating agents & $\uparrow$ & [104-106] \\
\hline
\end{tabular}


Table 1. Cont.

\begin{tabular}{|c|c|c|c|c|}
\hline $\begin{array}{l}\text { Gene (Gene ID *; Origin } \\
\text { If Different) }\end{array}$ & Cells & Agents & $\mathbf{R} *$ & References \\
\hline \multirow{4}{*}{$\begin{array}{l}\text { Ada }(946710 ; \text { E. coli) and its } \\
\text { truncated and modified versions }\end{array}$} & Mammalian cells & alkylating agents & $\uparrow$ & [104-117] \\
\hline & Chinese hamster lung fibroblasts & dibromoalkanes & $\downarrow$ & [105] \\
\hline & Chinese hamster (V79) & MMS, $\mathrm{HN}_{2}$ & 0 & [114] \\
\hline & Chinese hamster (CHO) & UV, ENU & 0 & [112] \\
\hline \multirow{2}{*}{$\begin{array}{l}\text { MGMT }(4255) \text { and its } \\
\text { modified versions }\end{array}$} & Mammalian cells & alkylating agents & $\uparrow$ & {$[112,118-125]$} \\
\hline & Chinese hamster (CHO) & UV, ENU & 0 & [112] \\
\hline alkB (946708; E. coli) & Human cervix adenocarcinoma (HeLa) & MMS, DMS & $\uparrow$ & [126] \\
\hline \multicolumn{5}{|c|}{ Genes involved in detoxification and efflux of free radicals and xenobiotics } \\
\hline \multirow{8}{*}{ SOD1 (6647) } & Human lymphoblastoid cells (TK6) & $\gamma$-ray & 0 & [127] \\
\hline & Human primary lung fibroblasts (HPLF) & $\gamma$-ray & $\uparrow$ & [128] \\
\hline & Astrocytes of mice & $\begin{array}{l}\text { xanthine oxidase with } \\
\text { hypoxanthine, menadione }\end{array}$ & $\uparrow$ & [129] \\
\hline & \multirow[t]{3}{*}{ Brain neurons of mice } & $\begin{array}{l}S \text {-nitroso- } N \text {-acetylpenicillamine, } \\
\text { spermine-NONOate, } \\
\text { diethylamine-NONOate }\end{array}$ & $\uparrow$ & [130] \\
\hline & & $\mathrm{H}_{2} \mathrm{O}_{2}$ & 0 & [130] \\
\hline & & menadione & $\downarrow$ & {$[130]$} \\
\hline & Normal human keratinocytes & UV & 0 & [131] \\
\hline & Human glioma cells (U118-9) & $\gamma$-ray & $\uparrow$ & [132] \\
\hline \multirow{5}{*}{ SOD2 (6648) } & \multirow{5}{*}{$\begin{array}{l}\text { Human lung adenocarcinoma } \\
\text { Human cells } \\
\text { Human lymphoblastoid cells (TK6) } \\
\text { Human hepatocellular carcinoma cells } \\
\text { (HLE) } \\
\text { Human gastric carcinoma cells } \\
\end{array}$} & cisplatin & $\uparrow$ & [133] \\
\hline & & $\gamma$-ray & $\uparrow$ & {$[127,128,134,135]$} \\
\hline & & paraquat & $\uparrow$ & [127] \\
\hline & & X-ray & $\uparrow$ & [136] \\
\hline & & doxorubicin & $\uparrow$ & [37] \\
\hline ALDH3A1 (218) & Human adenocarcinoma cells (MCF7) & $\begin{array}{l}\text { 4-hydroxyperoxycyclophosphamide, } \\
\text { doxorubicin, etoposide, } \\
\text { 5-fluorouracil, } \gamma \text {-ray, } \mathrm{H}_{2} \mathrm{O}_{2}\end{array}$ & $\uparrow$ & [137] \\
\hline \multirow{2}{*}{ CAT (847) } & Normal human keratinocytes & UV & $\uparrow$ & [131] \\
\hline & Mouse aortic endothelial cells (MAECs) & benzo(a)pyrene & $\uparrow$ & [138] \\
\hline TRX (41737) & Drosophila S2 Cells & $\mathrm{H}_{2} \mathrm{O}_{2}$ & $\uparrow$ & [139] \\
\hline \multirow{6}{*}{ MTII (17750) } & \multirow[t]{3}{*}{ Chinese hamster ovary cells (K1-2) } & $\begin{array}{l}\text { Cadmium chloride, MNU, MNNG } \\
\gamma \text {-ray, bleomycin, MMS, }\end{array}$ & $\uparrow$ & [140] \\
\hline & & $N$-hydroxyethyl- & 0 & [140] \\
\hline & & $\mathrm{N}$-hloroethylnitrosourea & & \\
\hline & & cisplatin, melphalan, chlorambucil & $\uparrow$ & [141] \\
\hline & Mouse C127 & 5-fluorouracil, vincristine & 0 & [141] \\
\hline & Mouse $\beta$-cell & streptozotocin & $\uparrow$ & [129] \\
\hline \multirow{4}{*}{ MTI (17748) } & Mouse embryo fibroblasts (NIH/3T3) & tert-butyl hydroperoxide & $\uparrow$ & [142] \\
\hline & \multirow{3}{*}{ Chinese hamster (V79) } & $\begin{array}{l}\text { Amsacrine, menadione, arsenite, } \\
\text { TPA }\end{array}$ & $\uparrow$ & {$[143]$} \\
\hline & & $\mathrm{Zn}(\mathrm{II})$ & $\uparrow$ & [144] \\
\hline & & alkylating agents & 0 & [144] \\
\hline \multicolumn{5}{|c|}{ Genes involved in control of proliferation and cell cycle } \\
\hline CCND1 (595) & Human adenocarcinoma cells (MCF7) & $\gamma$-ray & $\downarrow$ & [145] \\
\hline$p 21(1026)$ & $\begin{array}{l}\text { Glioma cells (T-98G, U-251MG with } \\
\text { mutant p53 allele and U-87MG with } \\
\text { wild-type p53). Medulloblastoma } \\
\text { cells MED-3. }\end{array}$ & $\gamma$-ray & $\uparrow$ & [146] \\
\hline \multicolumn{5}{|c|}{ Genes involved in regulation of apoptosis } \\
\hline \multirow{6}{*}{$B C L 2$ (596) } & \multirow{6}{*}{$\begin{array}{l}\text { Mice thymocytes } \\
\text { Rat } 6 \text { fibroblast (R6) } \\
\text { Human bladder cancer cells BIU87 } \\
\text { Mouse embryo fibroblasts (NIH/3T3) } \\
\text { Human breast cancer cells } \\
\text { (MDA-MB-231) } \\
\text { Human non-small cell lung } \\
\text { carcinoma (H1299) }\end{array}$} & Ionizing radiation (not specified) & $\uparrow \uparrow$ & [147] \\
\hline & & UV & $\uparrow$ & [148] \\
\hline & & adriamycin & $\uparrow$ & [149] \\
\hline & & $\gamma$-ray & $\uparrow$ & [150] \\
\hline & & $\gamma$-ray & $\uparrow$ & {$[150]$} \\
\hline & & Ionizing radiation (not specified) & $\downarrow$ & [151] \\
\hline \multicolumn{5}{|l|}{ Genes with other function } \\
\hline USP22 (23326) & Human lung carcinoma cells (A549) & cisplatin & $\uparrow$ & [152] \\
\hline IGF1R (3480) & Mammalian cells & $\gamma$-ray & $\uparrow$ & [153-157] \\
\hline \multirow{5}{*}{ Sirt1 (23411) } & \multirow{5}{*}{$\begin{array}{l}\text { Hepatocellular carcinoma cells (SK-Hep1) } \\
\text { Human skin fibroblasts (HS27) } \\
\text { Human endometrial carcinoma } \\
\text { cells (HHUA) } \\
\text { Human gastric cancer cells (SGC7901) } \\
\text { Normal human foreskin } \\
\text { fibroblasts (HCA2) }\end{array}$} & doxorubicin & $\uparrow$ & [158] \\
\hline & & UV & $\uparrow$ & [159] \\
\hline & & cisplatin & $\uparrow$ & [160] \\
\hline & & adriamycin, cisplatin, fluorouracil & $\uparrow$ & [161] \\
\hline & & Endonuclease induced DBS & 0 & [162] \\
\hline
\end{tabular}


Table 1. Cont.

\begin{tabular}{|c|c|c|c|c|}
\hline $\begin{array}{l}\text { Gene (Gene ID *; Origin } \\
\text { If Different) }\end{array}$ & Cells & Agents & $\mathbf{R} *$ & References \\
\hline Sirt2 (22933) & $\begin{array}{l}\text { Normal human foreskin fibroblasts } \\
\text { (HCA2) }\end{array}$ & Endonuclease induced DBS & 0 & [162] \\
\hline NAMPT (10135) & $\begin{array}{l}\text { Human prostate adenocarcinoma cells } \\
(\mathrm{LNCaP})\end{array}$ & $\mathrm{H}_{2} \mathrm{O}_{2}$ & $\uparrow$ & [163] \\
\hline VASH1 (22846) & $\begin{array}{l}\text { Human umbilical vein/vascular } \\
\text { endothelium cells (HUVECs) }\end{array}$ & $\mathrm{H}_{2} \mathrm{O}_{2}$ & $\uparrow$ & [164] \\
\hline Sirt6 (51548) & $\begin{array}{l}\text { Normal human foreskin fibroblasts } \\
\text { (HCA2) }\end{array}$ & $\begin{array}{l}\text { Endonuclease induced DBS, } \\
\text { paraquat, neocarzinostatin }\end{array}$ & $\uparrow$ & [162] \\
\hline \multirow[b]{2}{*}{ Sirt7 (51547) } & \multirow{2}{*}{$\begin{array}{l}\text { Mouse embryo fibroblasts (NIH/3T3) } \\
\text { Normal human foreskin fibroblasts } \\
\text { (HCA2) }\end{array}$} & doxorubicin & $\uparrow$ & [165] \\
\hline & & Endonuclease induced DBS & $\uparrow$ & [162] \\
\hline BRCC3 (79184) & Nasopharyngeal carcinoma cells (CNE2) & X-ray & $\uparrow$ & [166] \\
\hline Bmi1 (12151) & Mice hematopoietic stem cells & $\gamma$-ray & 0 & [167] \\
\hline STAT1 (6772) & $\begin{array}{l}\text { Human head and neck squamous cell } \\
\text { carcinoma cells (SCC-61) }\end{array}$ & X-ray & $\uparrow$ & [45] \\
\hline SLC25A11 (67863) & Mouse motoneuron-like cells (NSC34) & $\begin{array}{l}\mathrm{H}_{2} \mathrm{O}_{2} \text {, ethacrynic acid, sodium } \\
\text { nitroprusside }\end{array}$ & $\uparrow$ & [168] \\
\hline ICAM-3 (3385) & Human lung carcinoma cells (H1299) & $\gamma$-ray & $\uparrow$ & [40] \\
\hline AKR1C3 (8644) & Human prostate cells (DU145) & $6 \mathrm{MV}$ photons & $\uparrow$ & [169] \\
\hline $\operatorname{Pin1}(5300)$ & Cervix epidermoid carcinoma (Me180) & cisplatin & $\uparrow$ & [170] \\
\hline PVT1 (5820) & Human cancer cell lines & cisplatin & $\uparrow$ & {$[171,172]$} \\
\hline WRAP53 (55135) & Human osteosarcoma cells (U2OS) & $\gamma$-ray & $\uparrow$ & {$[173]$} \\
\hline \multirow[b]{2}{*}{ TRF2 (7014) } & \multirow{2}{*}{$\begin{array}{l}\text { Human fibroblasts (MRC-5) } \\
\text { Normal human foreskin fibroblasts } \\
\text { (HCA2) }\end{array}$} & $\mathrm{H}_{2} \mathrm{O}_{2}$ & $\uparrow$ & {$[174]$} \\
\hline & & Endonuclease induced DBS & $\uparrow$ & {$[175]$} \\
\hline MYC (4609) & Normal human foreskin fibroblasts & $\gamma$-ray & $\downarrow$ & [176] \\
\hline TEIF (57410) & Human cervix adenocarcinoma (HeLa) & $\mathrm{H}_{2} \mathrm{O}_{2}$ & $\uparrow$ & [177] \\
\hline \multirow{3}{*}{ PARP1 (142) } & Rat ovarian tumor cells (O-342) & $\gamma$-ray, MNNG & $\begin{array}{l}\downarrow \\
0\end{array}$ & {$[178]$} \\
\hline & Chinese hamster (C060) & $\gamma$-ray & $\downarrow$ & [179] \\
\hline & Chinese hamster ( $\mathrm{CHO})$ & UV, MMS & $\uparrow$ & [180] \\
\hline HOTAIR (100124700) & Human ovarian carcinoma cells (2780) & cisplatin & $\uparrow$ & [181] \\
\hline \multirow{2}{*}{ RPS3 (42761; Drosophila) } & $\begin{array}{l}\text { Human bone marrow cells from Fanconi } \\
\text { anemia patients }\end{array}$ & mitomycin $C$ & $\uparrow$ & [182] \\
\hline & Drosophila S2 cells & $\begin{array}{l}\text { paraquat, } \mathrm{H}_{2} \mathrm{O}_{2} \\
S \text {-nitroso- } N \text {-acetylpenicillamine }\end{array}$ & $\begin{array}{l}\downarrow \\
\uparrow\end{array}$ & $\begin{array}{l}{[100]} \\
{[100]}\end{array}$ \\
\hline RPS3 (6188) & Human skin fibroblasts & UV & $\uparrow$ & [183] \\
\hline CAIII (54232; rat) & Mouse embryo fibroblasts (NIH/3T3) & $\mathrm{H}_{2} \mathrm{O}_{2}$ & $\uparrow$ & [184] \\
\hline $\begin{array}{l}\text { constitutively active } P I 3 K p 110 \\
(170911)\end{array}$ & $\begin{array}{l}\text { Rat embryo fibroblasts (MR4) and human } \\
\text { papilloma cells (RT4) }\end{array}$ & $\gamma$-ray & $\uparrow$ & [26] \\
\hline \multirow{4}{*}{ p53 (7157) } & $\begin{array}{l}\text { Multidrug resistant human osteosarcoma } \\
\text { cells (U-2OSR2 and KHOSR2) }\end{array}$ & taxol, cisplatin, doxorubicin & $\downarrow$ & [185] \\
\hline & $\begin{array}{l}\text { Human non-small cell lung cancer } \\
\text { (A549, H1299) and colon cancer cell lines } \\
\text { (HCT116 p53+/+, HCT116 p53-/-) }\end{array}$ & bleomycin & $\downarrow$ & [186] \\
\hline & $\begin{array}{l}\text { Human non-small cell lung cancer } \\
\text { (A549; H1299; H358) }\end{array}$ & cisplatin, paclitaxel & $\downarrow$ & [187] \\
\hline & Human colon cancer cells (HT29) & $\gamma$-ray & $\downarrow 0$ & [188] \\
\hline SMAR1 (54971) & Human adenocarcinoma cells (MCF7) & Irradiation by ${ }^{89} \mathrm{SrCl} 2$ & $\downarrow$ & [189] \\
\hline
\end{tabular}

Gene ID *-EntrezGene ID for the organism from which the cDNA originated. When listed experiments performed in different species the human EntrezGene ID are specified. $\mathrm{R} *$-resistance estimated based on survival, growth inhibition, DNA damage and mutagenesis andpoints. MNU- $N$-methyl- $N$-nitrosourea; ENU— $N$-ethyl- $N$-nitrosourea; MMS-methylmethanesulphonate; EMS—ethylmethanesulfonate; MNNG$N$-methyl- $N$ '-nitro- $N$-nitrosoguanidine; DMS—dimethylsulfate. 
Table 2. Effect of overexpression of stress responsive genes on resistance to genotoxic agents in vivo.

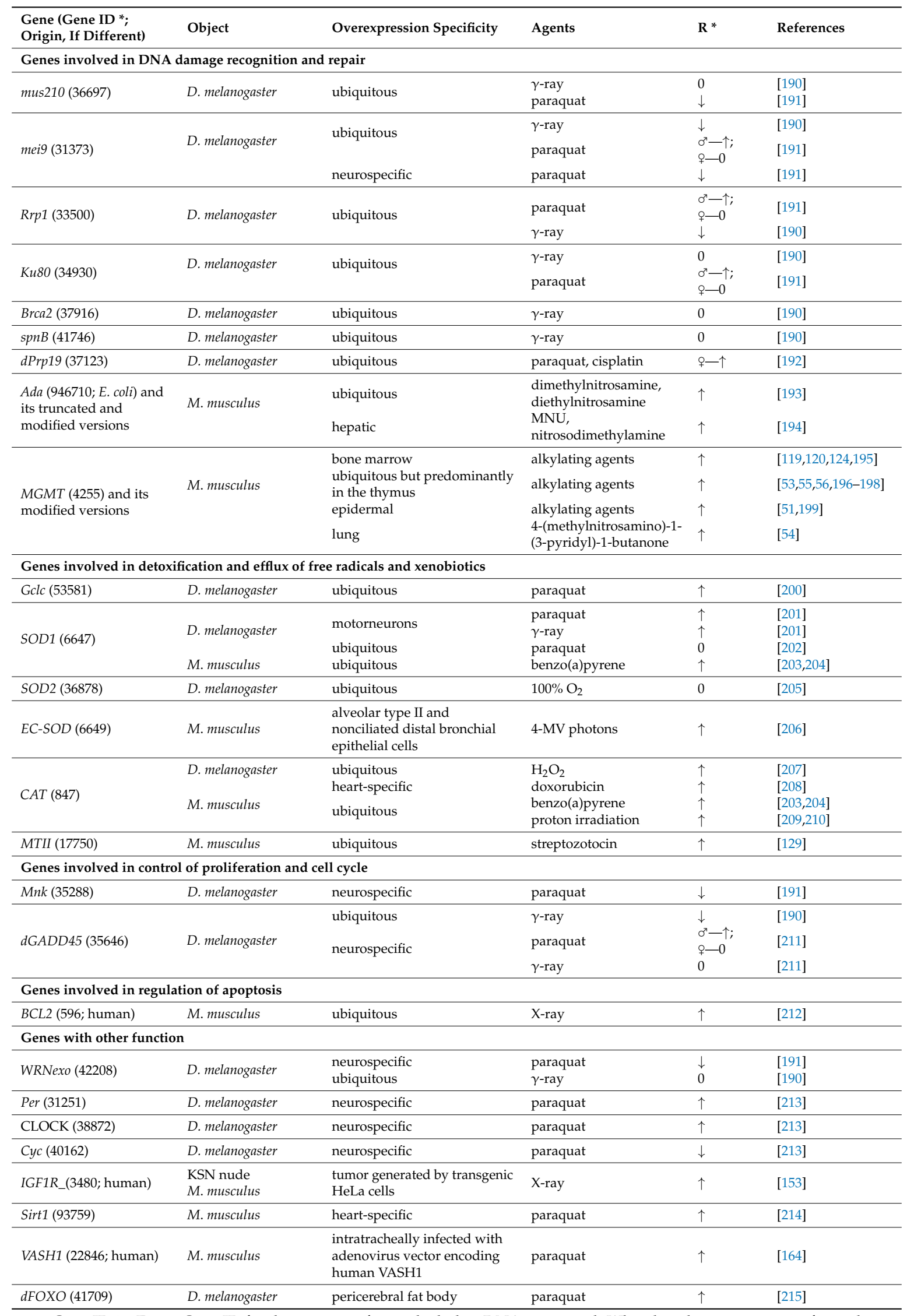

Gene ID *-EntrezGene ID for the organism from which the cDNA originated. When listed experiments performed in different species the human EntrezGene ID are specified. $R *$ - resistance estimated based on survival, growth inhibition, DNA damage, mutagenesis or neoplastic transformation andpoints. 
Acknowledgments: We thank Dmitry Klokov and Elena Belykh for critically reading and correcting the manuscript. The work was supported by a Grant of The President of The Russian Federation (MK-2929.2017.4).

Conflicts of Interest: The authors declare no conflict of interest.

\section{References}

1. Slupphaug, G.; Kavli, B.; Krokan, H.E. The interacting pathways for prevention and repair of oxidative DNA damage. Mutat. Res. 2003, 531, 231-251. [CrossRef] [PubMed]

2. Ciccia, A.; Elledge, S.J. The DNA damage response: Making it safe to play with knives. Mol. Cell 2010, 40, 179-204. [CrossRef] [PubMed]

3. Rafferty, J.A.; Hickson, I.; Chinnasamy, N.; Lashford, L.S.; Margison, G.P.; Dexter, T.M.; Fairbairn, L.J. Chemoprotection of normal tissues by transfer of drug resistance genes. Cancer Metastasis Rev. 1996, 15, 365-383. [CrossRef] [PubMed]

4. Allay, J.A.; Koç, O.N.; Davis, B.M.; Gerson, S.L. Retroviral-mediated gene transduction of human alkyltransferase complementary DNA confers nitrosourea resistance to human hematopoietic progenitors. Clin. Cancer Res. 1996, 2, 1353-1359. [PubMed]

5. Hickson, I.; Fairbairn, L.J.; Chinnasamy, N.; Dexter, T.M.; Margison, G.P.; Rafferty, J.A. Protection of mammalian cells against chloroethylating agent toxicity by an $\mathrm{O}^{6}$-benzylguanine-resistant mutant of human $\mathrm{O}^{6}$-alkylguanine-DNA alkyltransferase. Gene Ther. 1996, 3, 868-877. [PubMed]

6. Frosina, G. Gene prophylaxis by a DNA repair function. Mol. Asp. Med. 2007, 28, 323-344. [CrossRef] [PubMed]

7. Moskalev, A.A.; Shaposhnikov, M.V.; Plyusnina, E.N.; Zhavoronkov, A.; Budovsky, A.; Yanai, H.; Fraifeld, V.E. The role of DNA damage and repair in aging through the prism of Koch-like criteria. Ageing Res. Rev. 2013, 12, 661-684. [CrossRef] [PubMed]

8. Kudryavtseva, A.V.; Krasnov, G.S.; Dmitriev, A.A.; Alekseev, B.Y.; Kardymon, O.L.; Sadritdinova, A.F.; Fedorova, M.S.; Pokrovsky, A.V.; Melnikova, N.V.; Kaprin, A.D.; et al. Mitochondrial dysfunction and oxidative stress in aging and cancer. Oncotarget 2016, 7, 44879-44905. [CrossRef] [PubMed]

9. Abdallah, N.A.; Prakash, C.S.; McHughen, A.G. Genome editing for crop improvement: Challenges and opportunities. GM Crops Food 2015, 6, 183-205. [CrossRef] [PubMed]

10. Cucinotta, F.A.; Kim, M.-H.Y.; Chappell, L.J.; Huff, J.L. How Safe Is Safe Enough? Radiation Risk for a Human Mission to Mars. PLoS ONE 2013, 8. [CrossRef] [PubMed]

11. Voglauer, R.; Chang, M.W.-F.; Dampier, B.; Wieser, M.; Baumann, K.; Sterovsky, T.; Schreiber, M.; Katinger, H.; Grillari, J. SNEV overexpression extends the life span of human endothelial cells. Exp. Cell Res. 2006, 312, 746-759. [CrossRef] [PubMed]

12. Zhao, X.; Guo, J.; Yu, Y.; Yi, S.; Yu, T.; Fu, L.; Hou, L.; Chen, W. Overexpression of survivin and cyclin $\mathrm{D} 1$ in $\mathrm{CHO}$ cells confers apoptosis resistance and enhances growth in serum-free suspension culture. Biotechnol. Lett. 2011, 33, 1293-1300. [CrossRef] [PubMed]

13. Jiang, F.; Doudna, J.A. CRISPR-Cas9 Structures and Mechanisms. Annu. Rev. Biophys. 2017, 46, 505-529. [CrossRef] [PubMed]

14. Gilbert, L.A.; Larson, M.H.; Morsut, L.; Liu, Z.; Brar, G.A.; Torres, S.E.; Stern-Ginossar, N.; Brandman, O.; Whitehead, E.H.; Doudna, J.A.; et al. CRISPR-Mediated Modular RNA-Guided Regulation of Transcription in Eukaryotes. Cell 2013, 154, 442-451. [CrossRef] [PubMed]

15. Maeder, M.L.; Linder, S.J.; Cascio, V.M.; Fu, Y.; Ho, Q.H.; Joung, J.K. CRISPR RNA—Guided activation of endogenous human genes. Nat. Methods 2013, 10, 977-979. [CrossRef] [PubMed]

16. Chavez, A.; Scheiman, J.; Vora, S.; Pruitt, B.W.; Tuttle, M.; Iyer, E.P.R.; Lin, S.; Kiani, S.; Guzman, C.D.; Wiegand, D.J.; et al. Highly efficient Cas9-mediated transcriptional programming. Nat. Methods 2015, 12, 326-328. [CrossRef] [PubMed]

17. Hilton, I.B.; D’Ippolito, A.M.; Vockley, C.M.; Thakore, P.I.; Crawford, G.E.; Reddy, T.E.; Gersbach, C.A. Epigenome editing by a CRISPR-Cas9-based acetyltransferase activates genes from promoters and enhancers. Nat. Biotechnol. 2015, 33, 510-517. [CrossRef] [PubMed]

18. Klann, T.S.; Black, J.B.; Chellappan, M.; Safi, A.; Song, L.; Hilton, I.B.; Crawford, G.E.; Reddy, T.E.; Gersbach, C.A. CRISPR-Cas9 epigenome editing enables high-throughput screening for functional regulatory elements in the human genome. Nat. Biotechnol. 2017, 35, 561-568. [CrossRef] [PubMed] 
19. Garcia-Bloj, B.; Moses, C.; Sgro, A.; Plani-Lam, J.; Arooj, M.; Duffy, C.; Thiruvengadam, S.; Sorolla, A.; Rashwan, R.; Mancera, R.L.; et al. Waking up dormant tumor suppressor genes with zinc fingers, TALEs and the CRISPR/dCas9 system. Oncotarget 2016, 7, 60535-60554. [CrossRef] [PubMed]

20. Braun, C.J.; Bruno, P.M.; Horlbeck, M.A.; Gilbert, L.A.; Weissman, J.S.; Hemann, M.T. Versatile in vivo regulation of tumor phenotypes by dCas9-mediated transcriptional perturbation. Proc. Natl. Acad. Sci. USA 2016, 113, E3892-E3900. [CrossRef] [PubMed]

21. Gillet, J.-P.; Gottesman, M.M. Mechanisms of Multidrug Resistance in Cancer. In Multi-Drug Resistance in Cancer; Zhou, J., Ed.; Humana Press: Totowa, NJ, USA, 2010; Volume 596, pp. 47-76, ISBN 978-1-60761-415-9.

22. Bouwman, P.; Jonkers, J. The effects of deregulated DNA damage signalling on cancer chemotherapy response and resistance. Nat. Rev. Cancer 2012, 12, 587-598. [CrossRef] [PubMed]

23. Holohan, C.; Van Schaeybroeck, S.; Longley, D.B.; Johnston, P.G. Cancer drug resistance: An evolving paradigm. Nat. Rev. Cancer 2013, 13, 714-726. [CrossRef] [PubMed]

24. Al-Dimassi, S.; Abou-Antoun, T.; El-Sibai, M. Cancer cell resistance mechanisms: A mini review. Clin. Transl. Oncol. 2014, 16, 511-516. [CrossRef] [PubMed]

25. Bernhard, E.J.; Stanbridge, E.J.; Gupta, S.; Gupta, A.K.; Soto, D.; Bakanauskas, V.J.; Cerniglia, G.J.; Muschel, R.J.; McKenna, W.G. Direct evidence for the contribution of activated N-ras and K-ras oncogenes to increased intrinsic radiation resistance in human tumor cell lines. Cancer Res. 2000, 60, 6597-6600. [PubMed]

26. Gupta, A.K.; Bakanauskas, V.J.; Cerniglia, G.J.; Cheng, Y.; Bernhard, E.J.; Muschel, R.J.; McKenna, W.G. The Ras radiation resistance pathway. Cancer Res. 2001, 61, 4278-4282. [PubMed]

27. De Bacco, F.; Luraghi, P.; Medico, E.; Reato, G.; Girolami, F.; Perera, T.; Gabriele, P.; Comoglio, P.M.; Boccaccio, C. Induction of MET by Ionizing Radiation and Its Role in Radioresistance and Invasive Growth of Cancer. JNCI J. Natl. Cancer Inst. 2011, 103, 645-661. [CrossRef] [PubMed]

28. Fernandez-L, A.; Squatrito, M.; Northcott, P.; Awan, A.; Holland, E.C.; Taylor, M.D.; Nahlé, Z.; Kenney, A.M. Oncogenic YAP promotes radioresistance and genomic instability in medulloblastoma through IGF2-mediated Akt activation. Oncogene 2012, 31, 1923-1937. [CrossRef] [PubMed]

29. Ghisolfi, L.; Keates, A.C.; Hu, X.; Lee, D.; Li, C.J. Ionizing radiation induces stemness in cancer cells. PLOS ONE 2012, 7, e43628. [CrossRef] [PubMed]

30. Koike, K.; Abe, T.; Hisano, T.; Kubo, T.; Wada, M.; Kohno, K.; Kuwano, M. Overexpression of multidrug resistance protein gene in human cancer cell lines selected for drug resistance to epipodophyllotoxins. Jpn. J. Cancer Res. Gann 1996, 87, 765-772. [CrossRef] [PubMed]

31. Calcagno, A.M.; Ambudkar, S.V. Molecular Mechanisms of Drug Resistance in Single-Step and Multi-Step Drug-Selected Cancer Cells. In Multi-Drug Resistance in Cancer; Zhou, J., Ed.; Humana Press: Totowa, NJ, USA, 2010; Volume 596, pp. 77-93, ISBN 978-1-60761-415-9.

32. Breen, L.; Keenan, J.; Clynes, M. Generation of lung cancer cell line variants by drug selection or cloning. Methods Mol. Biol. 2011, 731, 125-133. [CrossRef] [PubMed]

33. Pisco, A.O.; Brock, A.; Zhou, J.; Moor, A.; Mojtahedi, M.; Jackson, D.; Huang, S. Non-Darwinian dynamics in therapy-induced cancer drug resistance. Nat. Commun. 2013, 4. [CrossRef] [PubMed]

34. Klein, H.L. The consequences of Rad51 overexpression for normal and tumor cells. DNA Repair 2008, 7, 686-693. [CrossRef] [PubMed]

35. Martin, L.P.; Hamilton, T.C.; Schilder, R.J. Platinum Resistance: The Role of DNA Repair Pathways. Clin. Cancer Res. 2008, 14, 1291-1295. [CrossRef] [PubMed]

36. Choi, J.Y.; Park, J.-M.; Yi, J.M.; Leem, S.-H.; Kang, T.-H. Enhanced nucleotide excision repair capacity in lung cancer cells by preconditioning with DNA-damaging agents. Oncotarget 2015, 6, 22575. [CrossRef] [PubMed]

37. Hur, G.-C.; Cho, S.J.; Kim, C.-H.; Kim, M.K.; Bae, S.I.; Nam, S.Y.; Park, J.-W.; Kim, W.H.; Lee, B.L. Manganese superoxide dismutase expression correlates with chemosensitivity in human gastric cancer cell lines. Clin. Cancer Res. 2003, 9, 5768-5775. [PubMed]

38. Zhang, D.J.; Xiang, J.; Wang, X.; Wang, J.; Xiao, J.C.; Xu, W.; Xu, H.; Xin, Y.; Zhang, L.Z.; Pei, D.S.; et al. RPA1 expression in esophageal carcinoma and its influence on radiosensitivity of esophageal carcinoma TE-1 cells. Panminerva Med. 2015, 57, 183-189. [PubMed]

39. Kitahara, O.; Katagiri, T.; Tsunoda, T.; Harima, Y.; Nakamura, Y. Classification of sensitivity or resistance of cervical cancers to ionizing radiation according to expression profiles of 62 genes selected by cDNA microarray analysis. Neoplasia 2002, 4, 295-303. [CrossRef] [PubMed] 
40. Chung, Y.M.; Kim, B.-G.; Park, C.-S.; Huh, S.J.; Kim, J.; Park, J.K.; Cho, S.M.; Kim, B.S.; Kim, J.S.; Yoo, Y.D.; et al. Increased expression of ICAM-3 is associated with radiation resistance in cervical cancer. Int. J. Cancer 2005, 117, 194-201. [CrossRef] [PubMed]

41. Fukuda, K.; Sakakura, C.; Miyagawa, K.; Kuriu, Y.; Kin, S.; Nakase, Y.; Hagiwara, A.; Mitsufuji, S.; Okazaki, Y.; Hayashizaki, Y.; et al. Differential gene expression profiles of radioresistant oesophageal cancer cell lines established by continuous fractionated irradiation. Br. J. Cancer 2004, 91, 1543-1550. [CrossRef] [PubMed]

42. Guo, W.-F.; Lin, R.-X.; Huang, J.; Zhou, Z.; Yang, J.; Guo, G.-Z.; Wang, S.-Q. Identification of differentially expressed genes contributing to radioresistance in lung cancer cells using microarray analysis. Radiat. Res. 2005, 164, 27-35. [CrossRef] [PubMed]

43. Hanna, E.; Shrieve, D.C.; Ratanatharathorn, V.; Xia, X.; Breau, R.; Suen, J.; Li, S. A novel alternative approach for prediction of radiation response of squamous cell carcinoma of head and neck. Cancer Res. 2001, 61, 2376-2380. [PubMed]

44. Guo, Y.; Zhu, X.-D.; Qu, S.; Li, L.; Su, F.; Li, Y.; Huang, S.-T.; Li, D.-R. Identification of genes involved in radioresistance of nasopharyngeal carcinoma by integrating gene ontology and protein-protein interaction networks. Int. J. Oncol. 2012, 40, 85-92. [CrossRef] [PubMed]

45. Khodarev, N.N.; Beckett, M.; Labay, E.; Darga, T.; Roizman, B.; Weichselbaum, R.R. STAT1 is overexpressed in tumors selected for radioresistance and confers protection from radiation in transduced sensitive cells. Proc. Natl. Acad. Sci. USA 2004, 101, 1714-1719. [CrossRef] [PubMed]

46. Souchek, J.J.; Baine, M.J.; Lin, C.; Rachagani, S.; Gupta, S.; Kaur, S.; Lester, K.; Zheng, D.; Chen, S.; Smith, L.; et al. Unbiased analysis of pancreatic cancer radiation resistance reveals cholesterol biosynthesis as a novel target for radiosensitisation. Br. J. Cancer 2014, 111, 1139-1149. [CrossRef] [PubMed]

47. Higo, M.; Uzawa, K.; Kouzu, Y.; Bukawa, H.; Nimura, Y.; Seki, N.; Tanzawa, H. Identification of candidate radioresistant genes in human squamous cell carcinoma cells through gene expression analysis using DNA microarrays. Oncol. Rep. 2005, 14, 1293-1298. [CrossRef] [PubMed]

48. Ogawa, K.; Utsunomiya, T.; Mimori, K.; Tanaka, F.; Haraguchi, N.; Inoue, H.; Murayama, S.; Mori, M. Differential gene expression profiles of radioresistant pancreatic cancer cell lines established by fractionated irradiation. Int. J. Oncol. 2006, 28, 705-713. [CrossRef] [PubMed]

49. Schneider, W.M.; Chevillotte, M.D.; Rice, C.M. Interferon-Stimulated Genes: A Complex Web of Host Defenses. Annu. Rev. Immunol. 2014, 32, 513-545. [CrossRef] [PubMed]

50. Sevilya, Z.; Leitner-Dagan, Y.; Pinchev, M.; Kremer, R.; Elinger, D.; Rennert, H.S.; Schechtman, E.; Freedman, L.S.; Rennert, G.; Paz-Elizur, T.; et al. Low Integrated DNA Repair Score and Lung Cancer Risk. Cancer Prev. Res. 2014, 7, 398-406. [CrossRef] [PubMed]

51. Becker, K.; Gregel, C.M.; Kaina, B. The DNA repair protein $O^{6}$-methylguanine-DNA methyltransferase protects against skin tumor formation induced by antineoplastic chloroethylnitrosourea. Cancer Res. 1997, 57, 3335-3338. [PubMed]

52. Sekiguchi, M.; Nakabeppu, Y.; Sakumi, K.; Tuzuki, T. DNA-repair methyltransferase as a molecular device for preventing mutation and cancer. J. Cancer Res. Clin. Oncol. 1996, 122, 199-206. [CrossRef] [PubMed]

53. Zaidi, N.H.; Pretlow, T.P.; O’Riordan, M.A.; Dumenco, L.L.; Allay, E.; Gerson, S.L. Transgenic expression of human MGMT protects against azoxymethane-induced aberrant crypt foci and G to A mutations in the K-ras oncogene of mouse colon. Carcinogenesis 1995, 16, 451-456. [CrossRef] [PubMed]

54. Liu, L.; Qin, X.; Gerson, S.L. Reduced lung tumorigenesis in human methylguanine DNA-Methyltransferase transgenic mice achieved by expression of transgene within the target cell. Carcinogenesis 1999, 20, 279-284. [CrossRef] [PubMed]

55. Allay, E.; Reese, J.S.; McGuire, E.A.; Koc, O.N.; Sedransk, N.; Gerson, S.L. Potentiation of lymphomagenesis by methylnitrosourea in mice transgenic for LMO 1 is blocked by $\mathrm{O}^{6}$-alkylguanine DNA-alkyltransferase. Oncogene 1997, 15, 2127-2132. [CrossRef] [PubMed]

56. Qin, X.; Zhou, H.; Liu, L.; Gerson, S.L. Transgenic expression of human MGMT blocks the hypersensitivity of PMS2-deficient mice to low dose MNU thymic lymphomagenesis. Carcinogenesis 1999, 20, 1667-1673. [CrossRef] [PubMed]

57. Canitrot, Y.; Cazaux, C.; Fréchet, M.; Bouayadi, K.; Lesca, C.; Salles, B.; Hoffmann, J.-S. Overexpression of DNA polymerase $\beta$ in cell results in a mutator phenotype and a decreased sensitivity to anticancer drugs. Proc. Natl. Acad. Sci. USA 1998, 95, 12586-12590. [CrossRef] [PubMed] 
58. Canitrot, Y.; Frechet, M.; Servant, L.; Cazaux, C.; Hoffmann, J.S. Overexpression of DNA polymerase beta: A genomic instability enhancer process. FASEB J. 1999, 13, 1107-1111. [PubMed]

59. Chan, K.; Houlbrook, S.; Zhang, Q.-M.; Harrison, M.; Hickson, I.D.; Dianov, G.L. Overexpression of DNA polymerase results in an increased rate of frameshift mutations during base excision repair. Mutagenesis 2007, 22, 183-188. [CrossRef] [PubMed]

60. Luo, Q.; Lai, Y.; Liu, S.; Wu, M.; Liu, Y.; Zhang, Z. Deregulated expression of DNA polymerase $\beta$ is involved in the progression of genomic instability. Environ. Mol. Mutagen. 2012, 53, 325-333. [CrossRef] [PubMed]

61. Okuda, Y.; Nishi, R.; Ng, J.M.Y.; Vermeulen, W.; van der Horst, G.T.J.; Mori, T.; Hoeijmakers, J.H.J.; Hanaoka, F.; Sugasawa, K. Relative levels of the two mammalian Rad23 homologs determine composition and stability of the xeroderma pigmentosum group C protein complex. DNA Repair 2004, 3, 1285-1295. [CrossRef] [PubMed]

62. Wilhelm, M.; Schlegl, J.; Hahne, H.; Gholami, A.M.; Lieberenz, M.; Savitski, M.M.; Ziegler, E.; Butzmann, L.; Gessulat, S.; Marx, H.; et al. Mass-spectrometry-based draft of the human proteome. Nature 2014, 509, 582-587. [CrossRef] [PubMed]

63. Fortelny, N.; Overall, C.M.; Pavlidis, P.; Freue, G.V.C. Can we predict protein from mRNA levels? Nature 2017, 547, E19-E20. [CrossRef] [PubMed]

64. Kim, H.D.; Kim, T.-S.; Joo, Y.J.; Shin, H.-S.; Kim, S.-H.; Jang, C.-Y.; Lee, C.E.; Kim, J. RpS3 translation is repressed by interaction with its own mRNA. J. Cell. Biochem. 2010. [CrossRef] [PubMed]

65. Glassner, B.J.; Rasmussen, L.J.; Najarian, M.T.; Posnick, L.M.; Samson, L.D. Generation of a strong mutator phenotype in yeast by imbalanced base excision repair. Proc. Natl. Acad. Sci. USA 1998, 95, 9997-10002. [CrossRef] [PubMed]

66. Coquerelle, T.; Dosch, J.; Kaina, B. Overexpression of $N$-methylpurine-DNA glycosylase in Chinese hamster ovary cells renders them more sensitive to the production of chromosomal aberrations by methylating agents-A case of imbalanced DNA repair. Mutat. Res. Repair 1995, 336, 9-17. [CrossRef]

67. Schild, L.J.; Brookman, K.W.; Thompson, L.H.; Wilson, D.M. Effects of Ape1 overexpression on cellular resistance to DNA-damaging and anticancer agents. Somat. Cell Mol. Genet. 1999, 25, 253-262. [CrossRef] [PubMed]

68. Prieto-Alamo, M.J.; Laval, F. Overexpression of the human HAP1 protein sensitizes cells to the lethal effect of bioreductive drugs. Carcinogenesis 1999, 20, 415-419. [CrossRef] [PubMed]

69. Tsai, Y.-C.; Wang, Y.-H.; Liu, Y.-C. Overexpression of PCNA Attenuates Oxidative Stress-Caused Delay of Gap-Filling during Repair of UV-Induced DNA Damage. J. Nucleic Acids 2017, 2017, 1-12. [CrossRef] [PubMed]

70. Muruganujan, A.; Mi, H.; Casagrande, J.T.; Thomas, P.D. Large-scale gene function analysis with the PANTHER classification system. Nat. Protoc. 2013, 8, 1551. [CrossRef]

71. Mi, H.; Huang, X.; Muruganujan, A.; Tang, H.; Mills, C.; Kang, D.; Thomas, P.D. PANTHER version 11: Expanded annotation data from Gene Ontology and Reactome pathways, and data analysis tool enhancements. Nucleic Acids Res. 2017, 45, D183-D189. [CrossRef] [PubMed]

72. Pegram, M.D.; Finn, R.S.; Arzoo, K.; Beryt, M.; Pietras, R.J.; Slamon, D.J. The effect of HER-2/neu overexpression on chemotherapeutic drug sensitivity in human breast and ovarian cancer cells. Oncogene 1997, 15, 537-547. [CrossRef] [PubMed]

73. Sancar, A.; Lindsey-Boltz, L.A.; Ünsal-Kaçmaz, K.; Linn, S. Molecular Mechanisms of Mammalian DNA Repair and the DNA Damage Checkpoints. Annu. Rev. Biochem. 2004, 73, 39-85. [CrossRef] [PubMed]

74. Shao, S.; Chang, L.; Sun, Y.; Hou, Y.; Fan, X.; Sun, Y. Multiplexed sgRNA Expression Allows Versatile Single Nonrepetitive DNA Labeling and Endogenous Gene Regulation. ACS Synth. Biol. 2017. [CrossRef] [PubMed]

75. Qu, C.; Zhao, Y.; Feng, G.; Chen, C.; Tao, Y.; Zhou, S.; Liu, S.; Chang, H.; Zeng, M.; Xia, Y. RPA3 is a potential marker of prognosis and radioresistance for nasopharyngeal carcinoma. J. Cell. Mol. Med. 2017. [CrossRef] [PubMed]

76. Cleaver, J.E.; Charles, W.C.; McDowell, M.L.; Sadinski, W.J.; Mitchell, D.L. Overexpression of the XPA repair gene increases resistance to ultraviolet radiation in human cells by selective repair of DNA damage. Cancer Res. 1995, 55, 6152-6160. [PubMed]

77. Tomicic, M.; Eschbach, E.; Kaina, B. Expression of yeast but not human apurinic/apyrimidinic endonuclease renders Chinese hamster cells more resistant to DNA damaging agents. Mutat. Res. Repair 1997, 383, 155-165. [CrossRef] 
78. Herring, C.J.; Deans, B.; Elder, R.H.; Rafferty, J.A.; MacKinnon, J.; Barzilay, G.; Hickson, I.D.; Hendry, J.H.; Margison, G.P. Expression levels of the DNA repair enzyme HAP1 do not correlate with the radiosensitivities of human or HAP1-transfected rat cell lines. Br. J. Cancer 1999, 80, 940. [CrossRef] [PubMed]

79. Sossou, M. APE1 overexpression in XRCC1-deficient cells complements the defective repair of oxidative single strand breaks but increases genomic instability. Nucleic Acids Res. 2005, 33, 298-306. [CrossRef] [PubMed]

80. Hansen, W.K.; Deutsch, W.A.; Yacoub, A.; Xu, Y.; Williams, D.A.; Kelley, M.R. Creation of a Fully Functional Human Chimeric DNA Repair Protein COMBINING $O^{6}$-Methylguanine DNA Methyltransferase (MGMT) and AP Endonuclease (APE/Redoxeffector Factor 1 (Ref 1)) DNA Repair Proteins. J. Biol. Chem. 1998, 273, 756-762. [CrossRef] [PubMed]

81. Qi, D.; Hu, Y.; Zhang, Y.; Peng, T.; Ji, W. Effect of Ku70 expression on radiosensitivity in renal carcinoma 786-O cells. Cancer Cell Int. 2014, 14, 44. [CrossRef] [PubMed]

82. Kasten, U.; Borgmann, K.; Burgmann, P.; Li, G.; Dikomey, E. Overexpression of Human Ku70/Ku80 in Rat Cells Resulting in Reduced DSB Repair Capacity with Appropriate Increase in Cell Radiosensitivity but with No Effect on Cell Recovery. Radiat. Res. 1999, 151, 532. [CrossRef] [PubMed]

83. Shen, H.; Schultz, M.; Kruh, G.D.; Tew, K.D. Increased expression of DNA-dependent protein kinase confers resistance to adriamycin. Biochim. Biophys. Acta 1998, 1381, 131-138. [CrossRef]

84. Vispé, S.; Cazaux, C.; Lesca, C.; Defais, M. Overexpression of Rad51 protein stimulates homologous recombination and increases resistance of mammalian cells to ionizing radiation. Nucleic Acids Res. 1998, 26, 2859-2864. [CrossRef] [PubMed]

85. Rukść, A.; Birmingham, E.C.; Baker, M.D. Altered DNA repair and recombination responses in mouse cells expressing wildtype or mutant forms of RAD51. DNA Repair 2007, 6, 1876-1889. [CrossRef] [PubMed]

86. Lundin, C.; Schultz, N.; Arnaudeau, C.; Mohindra, A.; Hansen, L.T.; Helleday, T. RAD51 is Involved in Repair of Damage Associated with DNA Replication in Mammalian Cells. J. Mol. Biol. 2003, 328, 521-535. [CrossRef]

87. Ahel, D.; Horejsi, Z.; Wiechens, N.; Polo, S.E.; Garcia-Wilson, E.; Ahel, I.; Flynn, H.; Skehel, M.; West, S.C.; Jackson, S.P.; et al. Poly(ADP-ribose)-Dependent Regulation of DNA Repair by the Chromatin Remodeling Enzyme ALC1. Science 2009, 325, 1240-1243. [CrossRef] [PubMed]

88. Ho, E.L.Y. Repair of single-strand DNA interruptions by redundant pathways and its implication in cellular sensitivity to DNA-damaging agents. Nucleic Acids Res. 2003, 31, 7032-7040. [CrossRef] [PubMed]

89. Klungland, A.; Fairbairn, L.; Watson, A.J.; Margison, G.P.; Seeberg, E. Expression of the E. coli 3-methyladenine DNA glycosylase I gene in mammalian cells reduces the toxic and mutagenic effects of methylating agents. EMBO J. 1992, 11, 4439. [PubMed]

90. Klungland, A.; Bjørås, M.; Hoff, E.; Seeberg, E. Increased removal of 3-alkyladenine reduces the frequencies of hprt mutations induced by methyl- and ethylmethanesulfonate in Chinese hamster fibroblast cells. Nucleic Acids Res. 1994, 22, 1670-1674. [CrossRef] [PubMed]

91. Imperatori, L.; Damia, G.; Taverna, P.; Garattini, E.; Citti, L.; Boldrini, L.; D'Incalci, M. 3T3 NIH murine fibroblasts and B78 murine melanoma cells expressing the Escherichia coli N3-methyladenine-DNA glycosylase I do not become resistant to alkylating agents. Carcinogenesis 1994, 15, 533-537. [CrossRef] [PubMed]

92. Habraken, Y.; Laval, F. Increased resistance of the Chinese hamster mutant irsl cells to monofunctional alkylating agents by transfection of the E. coli or mammalian N3-methyladenine-DNA-glycosylase genes. Mutat. Res. Repair 1993, 293, 187-195. [CrossRef]

93. Calléja, F.; Jansen, J.G.; Vrieling, H.; Laval, F.; van Zeeland, A.A. Modulation of the toxic and mutagenic effects induced by methyl methanesulfonate in Chinese hamster ovary cells by overexpression of the rat N-alkylpurine-DNA glycosylase. Mutat. Res. Mol. Mech. Mutagen. 1999, 425, 185-194. [CrossRef]

94. Bramson, J.; O'Connor, T.; Panasci, L. Effect of alkyl-N-purine DNA glycosylase overexpression on cellular resistance to bifunctional alkylating agents. Biochem. Pharmacol. 1995, 50, 39-44. [CrossRef]

95. Ibeanu, G.; Hartenstein, B.; Dunn, W.C.; Chang, L.-Y.; Hofmann, E.; Coquerelle, T.; Mitra, S.; Kaina, B. Overexpression of human DNA repair protein $N$-methylpurine-DNA glycosylase results in the increased removal of $\mathrm{N}$-methylpurines in DNA without a concomitant increase in resistance to alkylating agents in Chinese hamster ovary cells. Carcinogenesis 1992, 13, 1989-1995. [CrossRef] [PubMed] 
96. Trivedi, R.N.; Almeida, K.H.; Fornsaglio, J.L.; Schamus, S.; Sobol, R.W. The role of base excision repair in the sensitivity and resistance to temozolomide-mediated cell death. Cancer Res. 2005, 65, 6394-6400. [CrossRef] [PubMed]

97. Trivedi, R.N.; Wang, X.-H.; Jelezcova, E.; Goellner, E.M.; Tang, J.-B.; Sobol, R.W. Human Methyl Purine DNA Glycosylase and DNA Polymerase Expression Collectively Predict Sensitivity to Temozolomide. Mol. Pharmacol. 2008, 74, 505-516. [CrossRef] [PubMed]

98. Laval, F. Expression of the E. coli fpg gene in mammalian cells reduces the mutagenicity of gamma-rays. Nucleic Acids Res. 1994, 22, 4943-4946. [CrossRef] [PubMed]

99. Cussac, C.; Laval, F. Reduction of the toxicity and mutagenicity of aziridine in mammalian cells harboring the Escherichia coli fpg gene. Nucleic Acids Res. 1996, 24, 1742-1746. [CrossRef] [PubMed]

100. Radyuk, S.N.; Michalak, K.; Rebrin, I.; Sohal, R.S.; Orr, W.C. Effects of ectopic expression of Drosophila DNA glycosylases dOgg1 and RpS3 in mitochondria. Free Radic. Biol. Med. 2006, 41, 757-764. [CrossRef] [PubMed]

101. Hollenbach, S.; Dhénaut, A.; Eckert, I.; Radicella, J.P.; Epe, B. Overexpression of Ogg1 in mammalian cells: Effects on induced and spontaneous oxidative DNA damage and mutagenesis. Carcinogenesis 1999, 20, 1863-1868. [CrossRef] [PubMed]

102. Bramson, J.; Panasci, L.C. Effect of ERCC-1 overexpression on sensitivity of Chinese hamster ovary cells to DNA damaging agents. Cancer Res. 1993, 53, 3237-3240. [PubMed]

103. Harrison, L.; Skorvaga, M.; Cunningham, R.P.; Hendry, J.H.; Margison, G.P. Transfection of the Escherichia coli nth Gene into Radiosensitive Chinese Hamster Cells: Effects on Sensitivity to Radiation, Hydrogen Peroxide, and Bleomycin Sulfate. Radiat. Res. 1992, 132, 30. [CrossRef] [PubMed]

104. Harris, L.C.; Margison, G.P. Expression in mammalian cells of the Escherichia coli $O^{6}$ alkylguanine-DNA-alkyltransferase gene ogt reduces the toxicity of alkylnitrosoureas. Br. J. Cancer 1993, 67, 1196-1202. [CrossRef] [PubMed]

105. Abril, N.; Margison, G.P. Mammalian Cells Expressing Escherichia coli $O^{6}$-Alkylguanine-DNA Alkyltransferases Are Hypersensitive to Dibromoalkanes. Chem. Res. Toxicol. 1999, 12, 544-551. [CrossRef] [PubMed]

106. Von Hofe, E.; Fairbairn, L.; Margison, G.P. Relationship between $O^{6}$-alkylguanine-DNA alkyltransferase activity and $N$-methyl- $N^{\prime}$-nitro- $N$-nitrosoguanidine-induced mutation, transformation, and cytotoxicity in $\mathrm{C} 3 \mathrm{H} / 10 \mathrm{~T} 1 / 2$ cells expressing exogenous alkyltransferase genes. Proc. Natl. Acad. Sci. USA 1992, 89, 11199-11203. [CrossRef] [PubMed]

107. Ishizaki, K.; Tsujimura, T.; Yawata, H.; Fujio, C.; Nakabeppu, Y.; Sekiguchi, M.; Ikenaga, M. Transfer of the E. coli $\mathrm{O}^{6}$-methyltransferase gene into repair-deficient human cells and restoration of cellular resistance to $N$-methyl- $N^{\prime}$-nitro-N-nitrosoguanidine. Mutat. Res. Repair Rep. 1986, 166, 135-141. [CrossRef]

108. Ishizaki, K.; Tsujimura, T.; Fujio, C.; Zhang, Y.P.; Yawata, H.; Nakabeppu, Y.; Sekiguchi, M.; Ikenaga, M. Expression of the truncated E. coli $\mathrm{O}^{6}$-methylguanine methyltransferase gene in repair-deficient human cells and restoration of cellular resistance to alkylating agents. Mutat. Res. 1987, 184, 121-128. [PubMed]

109. Dumenco, L.L.; Warman, B.; Hatzoglou, M.; Lim, I.K.; Abboud, S.L.; Gerson, S.L. Increase in nitrosourea resistance in mammalian cells by retrovirally mediated gene transfer of bacterial $O^{6}$-alkylguanine-DNA alkyltransferase. Cancer Res. 1989, 49, 6044-6051. [PubMed]

110. Lim, I.K.; Dumenco, L.L.; Hatzoglou, M.; Hanson, R.W.; Gerson, S.L. Increased drug resistance following retroviral gene transfer of a chimeric $P$-enolpyruvate carboxykinase (GTP)-bacterial $O^{6}$-alkylguanine-DNA alkyltransferase gene into NRK cells. Carcinogenesis 1990, 11, 737-743. [CrossRef] [PubMed]

111. Jelinek, J.; Kleibl, K.; Dexter, T.M.; Margison, G.P. Transfection of murine multi-potent haemopoietic stem cells with an E. coli DNA alkyltransferase gene confers resistance to the toxic effects of alkylating agents. Carcinogenesis 1988, 9, 81-87. [CrossRef] [PubMed]

112. Kaina, B.; Fritz, G.; Coquerelle, T. Identification of human genes involved in repair and tolerance of DNA damage. Radiat. Environ. Biophys. 1991, 30, 1-19. [CrossRef] [PubMed]

113. Kataoka, H.; Hall, J.; Karran, P. Complementation of sensitivity to alkylating agents in Escherichia coli and Chinese hamster ovary cells by expression of a cloned bacterial DNA repair gene. EMBO J. 1986, 5, 3195. [PubMed]

114. Brennand, J.; Margison, G.P. Expression in mammalian cells of a truncated Escherichia coli gene coding for $O^{6}$-alkylguanine alkyltransferase reduces the toxic effects of alkylating agents. Carcinogenesis 1986, 7 , 2081-2084. [CrossRef] [PubMed] 
115. Brennand, J.; Margison, G.P. Reduction of the toxicity and mutagenicity of alkylating agents in mammalian cells harboring the Escherichia coli alkyltransferase gene. Proc. Natl. Acad. Sci. USA 1986, 83, 6292-6296. [CrossRef] [PubMed]

116. White, G.R.; Ockey, C.H.; Brennand, J.; Margison, G.P. Chinese hamster cells harbouring the Escherichia coli $\mathrm{O}^{6}$-alkylguanine alkyltransferase gene are less susceptible to sister chromatid exchange induction and chromosome damage by methylating agents. Carcinogenesis 1986, 7, 2077-2080. [CrossRef] [PubMed]

117. Fox, M.; Brennand, J.; Margison, G.P. Protection of Chinese hamster cells against the cytotoxic and mutagenic effects of alkylating agents by transfection of the Escherichia coli alkyltransferase gene and a truncated derivative. Mutagenesis 1987, 2, 491-496. [CrossRef] [PubMed]

118. Minnick, D.T.; Gerson, S.L.; Dumenco, L.L.; Veigl, M.L.; Sedwick, W.D. Specificity of bischloroethylnitrosourea-induced mutation in a Chinese hamster ovary cell line transformed to express human $O^{6}$-alkylguanine-DNA alkyltransferase. Cancer Res. 1993, 53, 997-1003. [PubMed]

119. Allay, J.A.; Dumenco, L.L.; Koc, O.N.; Liu, L.; Gerson, S.L. Retroviral transduction and expression of the human alkyltransferase cDNA provides nitrosourea resistance to hematopoietic cells. Blood 1995, 85, 3342-3351. [PubMed]

120. Moritz, T.; Mackay, W.; Glassner, B.J.; Williams, D.A.; Samson, L. Retrovirus-mediated expression of a DNA repair protein in bone marrow protects hematopoietic cells from nitrosourea-induced toxicity in vitro and in vivo. Cancer Res. 1995, 55, 2608-2614. [PubMed]

121. Reese, J.S.; Koç, O.N.; Lee, K.M.; Liu, L.; Allay, J.A.; Phillips, W.P.; Gerson, S.L. Retroviral transduction of a mutant methylguanine DNA methyltransferase gene into human CD34 cells confers resistance to $O^{6}$-benzylguanine plus 1,3-bis(2-chloroethyl)-1-nitrosourea. Proc. Natl. Acad. Sci. USA 1996, 93, 14088-14093. [CrossRef] [PubMed]

122. Jelinek, J.; Fairbairn, L.J.; Dexter, T.M.; Rafferty, J.A.; Stocking, C.; Ostertag, W.; Margison, G.P. Long-term protection of hematopoiesis against the cytotoxic effects of multiple doses of nitrosourea by retrovirus-mediated expression of human $O^{6}$-alkylguanine-DNA-alkyltransferase. Blood 1996, 87, 1957-1961. [PubMed]

123. Reese, J.S.; Davis, B.M.; Liu, L.; Gerson, S.L. Simultaneous protection of G156A methylguanine DNA methyltransferase gene-transduced hematopoietic progenitors and sensitization of tumor cells using $\mathrm{O}^{6}$-benzylguanine and temozolomide. Clin. Cancer Res. 1999, 5, 163-169. [PubMed]

124. Maze, R.; Carney, J.P.; Kelley, M.R.; Glassner, B.J.; Williams, D.A.; Samson, L. Increasing DNA repair methyltransferase levels via bone marrow stem cell transduction rescues mice from the toxic effects of 1,3-bis(2-chloroethyl)-1-nitrosourea, a chemotherapeutic alkylating agent. Proc. Natl. Acad. Sci. USA 1996, 93, 206-210. [CrossRef] [PubMed]

125. Bignami, M.; Terlizzese, M.; Zijno, A.; Calcagnile, A.; Frosina, G.; Abbondandolo, A.; Dogliotti, E. Cytotoxicity, mutations and SCEs induced by methylating agents are reduced in $\mathrm{CHO}$ cells expressing an active mammalian $O^{6}$-methylguanine-DNA methyltransferase gene. Carcinogenesis 1987, 8, 1417-1421. [CrossRef] [PubMed]

126. Chen, B.J.; Carroll, P.; Samson, L. The Escherichia coli AlkB protein protects human cells against alkylation-induced toxicity. J. Bacteriol. 1994, 176, 6255-6261. [CrossRef] [PubMed]

127. Veldwijk, M.R.; Trah, J.; Wang, M.; Maier, P.; Fruehauf, S.; Zeller, W.J.; Herskind, C.; Wenz, F. Overexpression of Manganese Superoxide Dismutase Does Not Increase Clonogenic Cell Survival Despite Effect on Apoptosis in Irradiated Lymphoblastoid Cells. Radiat. Res. 2011, 176, 725-731. [CrossRef] [PubMed]

128. Veldwijk, M.R.; Herskind, C.; Sellner, L.; Radujkovic, A.; Laufs, S.; Fruehauf, S.; Zeller, W.J.; Wenz, F. Normal-Tissue Radioprotection by Overexpression of the Copper-Zinc and Manganese Superoxide Dismutase Genes. Strahlenther. Onkol. 2009, 185, 517-523. [CrossRef] [PubMed]

129. Chen, H.; Carlson, E.C.; Pellet, L.; Moritz, J.T.; Epstein, P.N. Overexpression of metallothionein in pancreatic $\beta$-cells reduces streptozotocin-induced DNA damage and diabetes. Diabetes 2001, 50, 2040-2046. [CrossRef] [PubMed]

130. Ying, W.; Anderson, C.M.; Chen, Y.; Stein, B.A.; Fahlman, C.S.; Copin, J.C.; Chan, P.H.; Swanson, R.A. Differing effects of copper, zinc superoxide dismutase overexpression on neurotoxicity elicited by nitric oxide, reactive oxygen species, and excitotoxins. J. Cereb. Blood Flow Metab. 2000, 20, 359-368. [CrossRef] [PubMed] 
131. Rezvani, H.R.; Mazurier, F.; Cario-André, M.; Pain, C.; Ged, C.; Taïeb, A.; de Verneuil, H. Protective Effects of Catalase Overexpression on UVB-induced Apoptosis in Normal Human Keratinocytes. J. Biol. Chem. 2006, 281, 17999-18007. [CrossRef] [PubMed]

132. Gao, Z.; Sarsour, E.H.; Kalen, A.L.; Li, L.; Kumar, M.G.; Goswami, P.C. Late ROS accumulation and radiosensitivity in SOD1-overexpressing human glioma cells. Free Radic. Biol. Med. 2008, 45, 1501-1509. [CrossRef] [PubMed]

133. Chen, P.-M.; Cheng, Y.-W.; Wu, T.-C.; Chen, C.-Y.; Lee, H. MnSOD overexpression confers cisplatin resistance in lung adenocarcinoma via the NF-kB/Snail/Bcl-2 pathway. Free Radic. Biol. Med. 2015, 79, 127-137. [CrossRef] [PubMed]

134. Fisher, C.J.; Goswami, P.C. Mitochondria-targeted antioxidant enzyme activity regulates radioresistance in human pancreatic cancer cells. Cancer Biol. Ther. 2008, 7, 1271-1279. [CrossRef] [PubMed]

135. Guo, G.; Yan-Sanders, Y.; Lyn-Cook, B.D.; Wang, T.; Tamae, D.; Ogi, J.; Khaletskiy, A.; Li, Z.; Weydert, C.; Longmate, J.A.; et al. Manganese Superoxide Dismutase-Mediated Gene Expression in Radiation-Induced Adaptive Responses. Mol. Cell. Biol. 2003, 23, 2362-2378. [CrossRef] [PubMed]

136. Motoori, S.; Majima, H.J.; Ebara, M.; Kato, H.; Hirai, F.; Kakinuma, S.; Yamaguchi, C.; Ozawa, T.; Nagano, T.; Tsujii, H.; et al. Overexpression of mitochondrial manganese superoxide dismutase protects against radiation-induced cell death in the human hepatocellular carcinoma cell line HLE. Cancer Res. 2001, 61, 5382-5388. [PubMed]

137. Voulgaridou, G.-P.; Kiziridou, M.; Mantso, T.; Chlichlia, K.; Galanis, A.; Koukourakis, M.I.; Franco, R.; Panayiotidis, M.I.; Pappa, A. Aldehyde dehydrogenase 3A1 promotes multi-modality resistance and alters gene expression profile in human breast adenocarcinoma MCF-7 cells. Int. J. Biochem. Cell Biol. 2016, 77, 120-128. [CrossRef] [PubMed]

138. Yang, F.; Yang, H.; Ramesh, A.; Goodwin, J.S.; Okoro, E.U.; Guo, Z. Overexpression of Catalase Enhances Benzo(a)pyrene Detoxification in Endothelial Microsomes. PLoS ONE 2016, 11, e0162561. [CrossRef] [PubMed]

139. Umeda-Kameyama, Y.; Tsuda, M.; Ohkura, C.; Matsuo, T.; Namba, Y.; Ohuchi, Y.; Aigaki, T. Thioredoxin Suppresses Parkin-associated Endothelin Receptor-like Receptor-induced Neurotoxicity and Extends Longevity in Drosoph. J. Biol. Chem. 2007, 282, 11180-11187. [CrossRef] [PubMed]

140. Kaina, B.; Lohrer, H.; Karin, M.; Herrlich, P. Overexpressed human metallothionein IIA gene protects Chinese hamster ovary cells from killing by alkylating agents. Proc. Natl. Acad. Sci. USA 1990, 87, 2710-2714. [CrossRef] [PubMed]

141. Kelley, S.L.; Basu, A.; Teicher, B.A.; Hacker, M.P.; Hamer, D.H.; Lazo, J.S. Overexpression of metallothionein confers resistance to anticancer drugs. Science 1988, 241, 1813-1815. [CrossRef] [PubMed]

142. Schwarz, M.A.; Lazo, J.S.; Yalowich, J.C.; Reynolds, I.; Kagan, V.E.; Tyurin, V.; Kim, Y.M.; Watkins, S.C.; Pitt, B.R. Cytoplasmic metallothionein overexpression protects NIH 3T3 cells from tert-butyl hydroperoxide toxicity. J. Biol. Chem. 1994, 269, 15238-15243. [PubMed]

143. Sarkar, B. (Ed.) Genetic Response to Metals; CRC Press: Boca Raton, FL, USA, 1995; ISBN 978-0-8247-9615-0.

144. Goncharova, E.I.; Rossman, T.G. A role for metallothionein and zinc in spontaneous mutagenesis. Cancer Res. 1994, 54, 5318-5323. [PubMed]

145. Coco Martin, J.M.; Balkenende, A.; Verschoor, T.; Lallemand, F.; Michalides, R. Cyclin D1 overexpression enhances radiation-induced apoptosis and radiosensitivity in a breast tumor cell line. Cancer Res. 1999, 59, 1134-1140. [PubMed]

146. Kokunai, T.; Tamaki, N. Relationship between expression of p21WAF1/CIP1 and radio resistance in human gliomas. Cancer Sci. 1999, 90, 638-646.

147. Sentman, C.L.; Shutter, J.R.; Hockenbery, D.; Kanagawa, O.; Korsmeyer, S.J. Bcl-2 inhibits multiple forms of apoptosis but not negative selection in thymocytes. Cell 1991, 67, 879-888. [CrossRef]

148. Pourzand, C.; Rossier, G.; Reelfs, O.; Borner, C.; Tyrrell, R.M. Overxpression of Bcl-2 inhibits UVA-mediated immediate apoptosiinrat 6 fibroblasts: Evidence for the involvement of $\mathrm{Bcl}-2$ as an antioxidant. Cancer Res. 1997, 57, 1405-1411. [PubMed]

149. Kong, C.-Z.; Zhang, Z. Bcl-2 Overexpression Inhibits Generation of Intracellular Reactive Oxygen Species and Blocks Adriamycin-induced Apoptosis in Bladder Cancer Cells. Asian Pac. J. Cancer Prev. 2013, 14, 895-901. [CrossRef] [PubMed] 
150. Itamochi, H.; Yamasaki, F.; Sudo, T.; Takahashi, T.; Bartholomeusz, C.; Das, S.; Terakawa, N.; Ueno, N.T. Reduction of radiation-induced apoptosis by specific expression of Bcl-2 in normal cells. Cancer Gene Ther. 2006, 13, 451-459. [CrossRef] [PubMed]

151. Wang, Q.; Gao, F.; May, W.S.; Zhang, Y.; Flagg, T.; Deng, X. Bcl2 Negatively Regulates DNA Double-Strand-Break Repair through a Nonhomologous End-Joining Pathway. Mol. Cell 2008, 29, 488-498. [CrossRef] [PubMed]

152. Wang, A.; Ning, Z.; Lu, C.; Gao, W.; Liang, J.; Yan, Q.; Tan, G.; Liu, J. USP22 Induces Cisplatin Resistance in Lung Adenocarcinoma by Regulating $\gamma \mathrm{H} 2 \mathrm{AX}-$ Mediated DNA Damage Repair and Ku70/Bax-Mediated Apoptosis. Front. Pharmacol. 2017, 8, 274. [CrossRef] [PubMed]

153. Kaneko, H.; Yu, D.; Miura, M. Overexpression of IGF-I receptor in HeLa cells enhances in vivo radioresponse. Biochem. Biophys. Res. Commun. 2007, 363, 937-941. [CrossRef] [PubMed]

154. Turner, B.C.; Haffty, B.G.; Narayanan, L.; Yuan, J.; Havre, P.A.; Gumbs, A.A.; Kaplan, L.; Burgaud, J.L.; Carter, D.; Baserga, R.; et al. Insulin-like growth factor-I receptor overexpression mediates cellular radioresistance and local breast cancer recurrence after lumpectomy and radiation. Cancer Res. 1997, 57, 3079-3083. [PubMed]

155. Nakamura, S.; Watanabe, H.; Miura, M.; Sasaki, T. Effect of the Insulin-like Growth Factor I Receptor on Ionizing Radiation-Induced Cell Death in Mouse Embryo Fibroblasts. Exp. Cell Res. 1997, 235, 287-294. [CrossRef] [PubMed]

156. Tezuka, M.; Watanabe, H.; Nakamura, S.; Yu, D.; Aung, W.; Sasaki, T.; Shibuya, H.; Miura, M. Antiapoptotic activity is dispensable for insulin-like growth factor I receptor-mediated clonogenic radioresistance after gamma-irradiation. Clin. Cancer Res. 2001, 7, 3206-3214. [PubMed]

157. Yu, D.; Watanabe, H.; Shibuya, H.; Miura, M. Redundancy of Radioresistant Signaling Pathways Originating from Insulin-like Growth Factor I Receptor. J. Biol. Chem. 2003, 278, 6702-6709. [CrossRef] [PubMed]

158. Chen, H.-C.; Jeng, Y.-M.; Yuan, R.-H.; Hsu, H.-C.; Chen, Y.-L. SIRT1 promotes tumorigenesis and resistance to chemotherapy in hepatocellular carcinoma and its expression predicts poor prognosis. Ann. Surg. Oncol. 2012, 19, 2011-2019. [CrossRef] [PubMed]

159. Chung, K.W.; Choi, Y.J.; Park, M.H.; Jang, E.J.; Kim, D.H.; Park, B.H.; Yu, B.P.; Chung, H.Y. Molecular Insights into SIRT1 Protection Against UVB-Induced Skin Fibroblast Senescence by Suppression of Oxidative Stress and p53 Acetylation. J. Gerontol. A Biol. Sci. Med. Sci. 2015, 70, 959-968. [CrossRef] [PubMed]

160. Asaka, R.; Miyamoto, T.; Yamada, Y.; Ando, H.; Mvunta, D.H.; Kobara, H.; Shiozawa, T. Sirtuin 1 promotes the growth and cisplatin resistance of endometrial carcinoma cells: A novel therapeutic target. Lab. Investig. 2015, 95, 1363-1373. [CrossRef] [PubMed]

161. Zhu, H.; Xia, L.; Zhang, Y.; Wang, H.; Xu, W.; Hu, H.; Wang, J.; Xin, J.; Gang, Y.; Sha, S.; et al. Activating Transcription Factor 4 Confers a Multidrug Resistance Phenotype to Gastric Cancer Cells through Transactivation of SIRT1 Expression. PLoS ONE 2012, 7, e31431. [CrossRef] [PubMed]

162. Mao, Z.; Hine, C.; Tian, X.; Van Meter, M.; Au, M.; Vaidya, A.; Seluanov, A.; Gorbunova, V. SIRT6 Promotes DNA Repair Under Stress by Activating PARP1. Science 2011, 332, 1443-1446. [CrossRef] [PubMed]

163. Wang, B.; Hasan, M.K.; Alvarado, E.; Yuan, H.; Wu, H.; Chen, W.Y. NAMPT overexpression in prostate cancer and its contribution to tumor cell survival and stress response. Oncogene 2011, 30, 907-921. [CrossRef] [PubMed]

164. Miyashita, H.; Watanabe, T.; Hayashi, H.; Suzuki, Y.; Nakamura, T.; Ito, S.; Ono, M.; Hoshikawa, Y.; Okada, Y.; Kondo, T.; et al. Angiogenesis Inhibitor Vasohibin-1 Enhances Stress Resistance of Endothelial Cells via Induction of SOD2 and SIRT1. PLoS ONE 2012, 7, e46459. [CrossRef] [PubMed]

165. Kiran, S.; Oddi, V.; Ramakrishna, G. Sirtuin 7 promotes cellular survival following genomic stress by attenuation of DNA damage, SAPK activation and p53 response. Exp. Cell Res. 2015, 331, 123-141. [CrossRef] [PubMed]

166. Tu, Z.; Xu, B.; Qu, C.; Tao, Y.; Chen, C.; Hua, W.; Feng, G.; Chang, H.; Liu, Z.; Li, G.; et al. BRCC3 acts as a prognostic marker in nasopharyngeal carcinoma patients treated with radiotherapy and mediates radiation resistance in vitro. Radiat. Oncol. 2015, 10. [CrossRef] [PubMed]

167. Nakamura, S.; Oshima, M.; Yuan, J.; Saraya, A.; Miyagi, S.; Konuma, T.; Yamazaki, S.; Osawa, M.; Nakauchi, H.; Koseki, H.; et al. Bmi1 Confers Resistance to Oxidative Stress on Hematopoietic Stem Cells. PLoS ONE 2012, 7, e36209. [CrossRef] [PubMed] 
168. Wilkins, H.M.; Brock, S.; Gray, J.J.; Linseman, D.A. Stable over-expression of the 2-oxoglutarate carrier enhances neuronal cell resistance to oxidative stress via Bcl-2-dependent mitochondrial GSH transport. J. Neurochem. 2014, 130, 75-86. [CrossRef] [PubMed]

169. Sun, S.-Q.; Gu, X.; Gao, X.-S.; Li, Y.; Yu, H.; Xiong, W.; Yu, H.; Wang, W.; Li, Y.; Teng, Y.; et al. Overexpression of AKR1C3 significantly enhances human prostate cancer cells resistance to radiation. Oncotarget 2016, 7, 48050-48058. [CrossRef] [PubMed]

170. Wang, T.; Liu, Z.; Shi, F.; Wang, J. Pin1 modulates chemo-resistance by up-regulating FoxM1 and the involvements of Wnt/ $\beta$-catenin signaling pathway in cervical cancer. Mol. Cell. Biochem. 2016, 413, 179-187. [CrossRef] [PubMed]

171. Zhang, X.; Bu, P.; Liu, L.; Zhang, X.; Li, J. Overexpression of long non-coding RNA PVT1 in gastric cancer cells promotes the development of multidrug resistance. Biochem. Biophys. Res. Commun. 2015, 462, 227-232. [CrossRef] [PubMed]

172. Liu, E.; Liu, Z.; Zhou, Y.; Mi, R.; Wang, D. Overexpression of long non-coding RNA PVT1 in ovarian cancer cells promotes cisplatin resistance by regulating apoptotic pathways. Int. J. Clin. Exp. Med. 2015, 8, 20565-20572. [PubMed]

173. Rassoolzadeh, H.; Böhm, S.; Hedström, E.; Gad, H.; Helleday, T.; Henriksson, S.; Farnebo, M. Overexpression of the scaffold WD40 protein WRAP53 $\beta$ enhances the repair of and cell survival from DNA double-strand breaks. Cell Death Dis. 2016, 7, e2267. [CrossRef] [PubMed]

174. Richter, T.; Saretzki, G.; Nelson, G.; Melcher, M.; Olijslagers, S.; von Zglinicki, T. TRF2 overexpression diminishes repair of telomeric single-strand breaks and accelerates telomere shortening in human fibroblasts. Mech. Ageing Dev. 2007, 128, 340-345. [CrossRef] [PubMed]

175. Mao, Z.; Seluanov, A.; Jiang, Y.; Gorbunova, V. TRF2 is required for repair of nontelomeric DNA double-strand breaks by homologous recombination. Proc. Natl. Acad. Sci. USA 2007, 104, 13068-13073. [CrossRef] [PubMed]

176. Karlsson, A.; Deb-Basu, D.; Cherry, A.; Turner, S.; Ford, J.; Felsher, D.W. Defective double-strand DNA break repair and chromosomal translocations by MYC overexpression. Proc. Natl. Acad. Sci. USA 2003, 100, 9974-9979. [CrossRef] [PubMed]

177. Zhao, Y.; Zheng, J.; Ling, Y.; Hou, L.; Zhang, B. Transcriptional upregulation of DNA polymerase $\beta$ by TEIF. Biochem. Biophys. Res. Commun. 2005, 333, 908-916. [CrossRef] [PubMed]

178. Bernges, F.; Bürkle, A.; Küpper, J.-H.; Zeller, W.J. Functional overexpression of human poly (ADP-ribose) polymerase in transfected rat tumor cells. Carcinogenesis 1997, 18, 663-668. [CrossRef] [PubMed]

179. Van Gool, L.; Meyer, R.; Tobiasch, E.; Cziepluch, C.; Jauniaux, J.C.; Mincheva, A.; Lichter, P.; Poirier, G.G.; Bürkle, A.; Küpper, J.H. Overexpression of human poly(ADP-ribose) polymerase in transfected hamster cells leads to increased poly(ADP-ribosyl)ation and cellular sensitization to gamma irradiation. Eur. J. Biochem. 1997, 244, 15-20. [CrossRef] [PubMed]

180. Fritz, G.; Auer, B.; Kaina, B. Effect of transfection of human poly(ADP-ribose)polymerase in Chinese hamster cells on mutagen resistance. Mutat. Res. 1994, 308, 127-133. [CrossRef]

181. Özeş, A.R.; Miller, D.F.; Özeş, O.N.; Fang, F.; Liu, Y.; Matei, D.; Huang, T.; Nephew, K.P. NF-kB-HOTAIR axis links DNA damage response, chemoresistance and cellular senescence in ovarian cancer. Oncogene 2016, 35, 5350-5361. [CrossRef] [PubMed]

182. Kelley, M.R.; Tritt, R.; Xu, Y.; New, S.; Freie, B.; Clapp, D.W.; Deutsch, W.A. The Drosophila S3 multifunctional DNA repair/ribosomal protein protects Fanconi anemia cells against oxidative DNA damaging agents. Mutat. Res. Repair 2001, 485, 107-119. [CrossRef]

183. Choi, S.H.; Kim, S.Y.; An, J.J.; Lee, S.H.; Kim, D.W.; Ryu, H.J.; Lee, N.I.; Yeo, S.I.; Jang, S.H.; Won, M.H.; et al. Human PEP-1-ribosomal protein S3 protects against UV-induced skin cell death. FEBS Lett. 2006, 580, 6755-6762. [CrossRef] [PubMed]

184. Räisänen, S.R.; Lehenkari, P.; Tasanen, M.; Rahkila, P.; Härkönen, P.L.; Väänänen, H.K. Carbonic anhydrase III protects cells from hydrogen peroxide-induced apoptosis. FASEB J. 1999, 13, 513-522. [CrossRef]

185. Ye, S.; Shen, J.; Choy, E.; Yang, C.; Mankin, H.; Hornicek, F.; Duan, Z. p53 overexpression increases chemosensitivity in multidrug-resistant osteosarcoma cell lines. Cancer Chemother. Pharmacol. 2016, 77, 349-356. [CrossRef] [PubMed]

186. Lee, Y.S.; Yoon, S.; Park, M.S.; Kim, J.H.; Lee, J.-H.; Song, C.-W. Influence of p53 expression on sensitivity of cancer cells to bleomycin. J. Biochem. Mol. Toxicol. 2010, 24, 260-269. [CrossRef] [PubMed] 
187. Guntur, V.P.; Waldrep, J.C.; Guo, J.J.; Selting, K.; Dhand, R. Increasing p53 protein sensitizes non-small cell lung cancer to paclitaxel and cisplatin in vitro. Anticancer Res. 2010, 30, 3557-3564. [PubMed]

188. Zellars, R.C.; Naida, J.D.; Davis, M.A.; Lawrence, T.S. Effect of p53 overexpression on radiation sensitivity of human colon cancer cells. Radiat. Oncol. Investig. 1997, 5, 43-49. [CrossRef]

189. Liu, H.; Ma, F.; Shen, Y.; Hu, Y.; Pan, S. Overexpression of SMAR1 Enhances Radiosensitivity in Human Breast Cancer Cell Line MCF7 via Activation of p53 Signaling Pathway. Oncol. Res. Featur. Preclin. Clin. Cancer Ther. 2015, 22, 293-300. [CrossRef] [PubMed]

190. Shilova, L.A.; Pliusnina, E.N.; Zemskaia, N.V.; Moskalev, A.A. Role of DNA repair genes in radiation-induced changes of lifespan of Drosophila melanogaster. Radiat. Biol. Radioecol. 2014, 54, 482-492.

191. Shaposhnikov, M.; Proshkina, E.; Shilova, L.; Zhavoronkov, A.; Moskalev, A. Lifespan and Stress Resistance in Drosophila with Overexpressed DNA Repair Genes. Sci. Rep. 2015, 5. [CrossRef] [PubMed]

192. Garschall, K.; Dellago, H.; Gáliková, M.; Schosserer, M.; Flatt, T.; Grillari, J. Ubiquitous overexpression of the DNA repair factor dPrp19 reduces DNA damage and extends Drosophila life span. NPJ Aging Mech. Dis. 2017, 3. [CrossRef]

193. Nakatsuru, Y.; Matsukuma, S.; Nemoto, N.; Sugano, H.; Sekiguchi, M.; Ishikawa, T. $O^{6}$-methylguanine-DNA methyltransferase protects against nitrosamine-induced hepatocarcinogenesis. Proc. Natl. Acad. Sci. USA 1993, 90, 6468-6472. [CrossRef] [PubMed]

194. Dumenco, L.L.; Arce, C.; Norton, K.; Yun, J.; Wagner, T.; Gerson, S.L. Enhanced repair of $O^{6}$-methylguanine DNA adducts in the liver of transgenic mice expressing the ada gene. Cancer Res. 1991, 51, 3391-3398. [PubMed]

195. Davis, B.M.; Reese, J.S.; Koç, O.N.; Lee, K.; Schupp, J.E.; Gerson, S.L. Selection for G156A $O^{6}$-methylguanine DNA methyltransferase gene-transduced hematopoietic progenitors and protection from lethality in mice treated with $O^{6}$-benzylguanine and 1, 3-bis(2-chloroethyl)-1-nitrosourea. Cancer Res. 1997, 57, 5093-5099. [PubMed]

196. Dumenco, L.L.; Allay, E.; Norton, K.; Gerson, S.L. The prevention of thymic lymphomas in transgenic mice by human $O^{6}$-alkylguanine-DNA alkyltransferase. Science 1993, 259, 219-222. [CrossRef] [PubMed]

197. Liu, L.; Allay, E.; Dumenco, L.L.; Gerson, S.L. Rapid repair of $O^{6}$-methylguanine-DNA adducts protects transgenic mice from N-methylnitrosourea-induced thymic lymphomas. Cancer Res. 1994, 54, 4648-4652. [PubMed]

198. Allay, E.; Veigl, M.; Gerson, S.L. Mice over-expressing human $O^{6}$ alkylguanine-DNA alkyltransferase selectively reduce $O^{6}$ methylguanine mediated carcinogenic mutations to threshold levels after $N$-methyl-N-nitrosourea. Oncogene 1999, 18, 3783-3787. [CrossRef] [PubMed]

199. Becker, K.; Dosch, J.; Gregel, C.M.; Martin, B.A.; Kaina, B. Targeted expression of human $\mathrm{O}^{6}$-methylguanine-DNA methyltransferase (MGMT) in transgenic mice protects against tumor initiation in two-stage skin carcinogenesis. Cancer Res. 1996, 56, 3244-3249. [PubMed]

200. Moskalev, A.; Shaposhnikov, M.; Proshkina, E.; Belyi, A.; Fedintsev, A.; Zhikrivetskaya, S.; Guvatova, Z.; Sadritdinova, A.; Snezhkina, A.; Krasnov, G.; et al. The influence of pro-longevity gene Gclc overexpression on the age-dependent changes in Drosophila transcriptome and biological functions. BMC Genom. 2016, 17. [CrossRef] [PubMed]

201. Parkes, T.L.; Elia, A.J.; Dickinson, D.; Hilliker, A.J.; Phillips, J.P.; Boulianne, G.L. Extension of Drosophila lifespan by overexpression of human SOD1 in motorneurons. Nat. Genet. 1998, 19, 171-174. [CrossRef] [PubMed]

202. Orr, W.C.; Sohal, R.S. Effects of Cu-Zn superoxide dismutase overexpression of life span and resistance to oxidative stress in transgenic Drosophila melanogaster. Arch. Biochem. Biophys. 1993, 301, 34-40. [CrossRef] [PubMed]

203. Yang, H.; Zhou, L.; Wang, Z.; Roberts, L.J.; Lin, X.; Zhao, Y.; Guo, Z. Overexpression of antioxidant enzymes in ApoE-deficient mice suppresses Benzo(a)pyrene-accelerated atherosclerosis. Atherosclerosis 2009, 207, 51-58. [CrossRef] [PubMed]

204. Wang, Z.; Yang, H.; Ramesh, A.; Roberts, L.J.; Zhou, L.; Lin, X.; Zhao, Y.; Guo, Z. Overexpression of $\mathrm{Cu} / \mathrm{Zn}$-superoxide dismutase and/or catalase accelerates Benzo(a)pyrene detoxification by upregulation of the aryl hydrocarbon receptor in mouse endothelial cells. Free Radic. Biol. Med. 2009, 47, 1221-1229. [CrossRef] [PubMed] 
205. Mockett, R.J.; Orr, W.C.; Rahmandar, J.J.; Benes, J.J.; Radyuk, S.N.; Klichko, V.I.; Sohal, R.S. Overexpression of Mn-containing superoxide dismutase in transgenic Drosophila melanogaster. Arch. Biochem. Biophys. 1999, 371, 260-269. [CrossRef] [PubMed]

206. Rabbani, Z.N.; Anscher, M.S.; Folz, R.J.; Archer, E.; Huang, H.; Chen, L.; Golson, M.L.; Samulski, T.S.; Dewhirst, M.W.; Vujaskovic, Z. Overexpression of extracellular superoxide dismutase reduces acute radiation induced lung toxicity. BMC Cancer 2005, 5. [CrossRef] [PubMed]

207. Sun, J.; Tower, J. FLP recombinase-mediated induction of $\mathrm{Cu} / \mathrm{Zn}$-superoxide dismutase transgene expression can extend the life span of adult Drosophila melanogaster flies. Mol. Cell. Biol. 1999, 19, 216-228. [CrossRef] [PubMed]

208. Kang, Y.J.; Chen, Y.; Epstein, P.N. Suppression of doxorubicin cardiotoxicity by overexpression of catalase in the heart of transgenic mice. J. Biol. Chem. 1996, 271, 12610-12616. [CrossRef] [PubMed]

209. Parihar, V.K.; Allen, B.D.; Tran, K.K.; Chmielewski, N.N.; Craver, B.M.; Martirosian, V.; Morganti, J.M.; Rosi, S.; Vlkolinsky, R.; Acharya, M.M.; et al. Targeted Overexpression of Mitochondrial Catalase Prevents Radiation-Induced Cognitive Dysfunction. Antioxid. Redox Signal. 2015, 22, 78-91. [CrossRef] [PubMed]

210. Liao, A.C.; Craver, B.M.; Tseng, B.P.; Tran, K.K.; Parihar, V.K.; Acharya, M.M.; Limoli, C.L. Mitochondrial-Targeted Human Catalase Affords Neuroprotection from Proton Irradiation. Radiat. Res. 2013, 180, 1-6. [CrossRef] [PubMed]

211. Moskalev, A.; Plyusnina, E.; Shaposhnikov, M.; Shilova, L.; Kazachenok, A.; Zhavoronkov, A. The role of D-GADD45 in oxidative, thermal and genotoxic stress resistance. Cell Cycle 2012, 11, 4222-4241. [CrossRef] [PubMed]

212. Domen, J.; Gandy, K.L.; Weissman, I.L. Systemic overexpression of BCL-2 in the hematopoietic system protects transgenic mice from the consequences of lethal irradiation. Blood 1998, 91, 2272-2282. [PubMed]

213. Dobrovol'skaya, E.V.; Solovyov, I.A.; Proshkina, E.N.; Moskalev, A.A. Effects of genes overactivation of circadian rhythms in different tissues to stress resistance and longevity of Drosophila melanogaster. Theor. Appl. Ecol. 2016, 32-40.

214. Alcendor, R.R.; Gao, S.; Zhai, P.; Zablocki, D.; Holle, E.; Yu, X.; Tian, B.; Wagner, T.; Vatner, S.F.; Sadoshima, J. Sirt1 Regulates Aging and Resistance to Oxidative Stress in the Heart. Circ. Res. 2007, 100, 1512-1521. [CrossRef] [PubMed]

215. Hwangbo, D.S.; Gershman, B.; Gersham, B.; Tu, M.-P.; Palmer, M.; Tatar, M. Drosophila dFOXO controls lifespan and regulates insulin signalling in brain and fat body. Nature 2004, 429, 562-566. [CrossRef] [PubMed]

(C) 2018 by the authors. Licensee MDPI, Basel, Switzerland. This article is an open access article distributed under the terms and conditions of the Creative Commons Attribution (CC BY) license (http:/ / creativecommons.org/licenses/by/4.0/). 